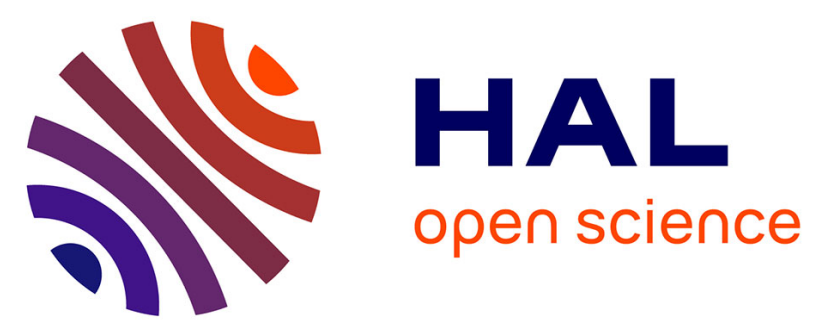

\title{
Dinuclear iridium and rhodium complexes with bridging arylimidazolide-N3,C2 ligands: synthetic, structural, reactivity, electrochemical and spectroscopic studies $\dagger$
}

Fan He, Laurent Ruhlmann, Jean-Paul Gisselbrecht, Sylvie Choua, Maylis Orio, Marcel Wesolek, Andreas D Danopoulos, Pierre Braunstein

\section{To cite this version:}

Fan He, Laurent Ruhlmann, Jean-Paul Gisselbrecht, Sylvie Choua, Maylis Orio, et al.. Dinuclear iridium and rhodium complexes with bridging arylimidazolide-N3,C2 ligands: synthetic, structural, reactivity, electrochemical and spectroscopic studiest. Dalton Transactions, 2015, 44, pp.17030-17044. 10.1039/c5dt02403j . hal-01442072

\section{HAL Id: hal-01442072 \\ https://hal.science/hal-01442072}

Submitted on 2 Feb 2017

HAL is a multi-disciplinary open access archive for the deposit and dissemination of scientific research documents, whether they are published or not. The documents may come from teaching and research institutions in France or abroad, or from public or private research centers.
L'archive ouverte pluridisciplinaire HAL, est destinée au dépôt et à la diffusion de documents scientifiques de niveau recherche, publiés ou non, émanant des établissements d'enseignement et de recherche français ou étrangers, des laboratoires publics ou privés. 


\section{Journal Name}

\section{ARTICLE}

\section{Dinuclear Iridium and Rhodium Complexes with Bridging Arylimidazolide- $N^{3}, C^{2}$ Ligands: Synthetic, Structural, Reactivity, Electrochemical and Spectroscopic Studies ${ }^{\dagger}$}

Received 00th January 20xx Accepted 00th January 20xx DOI: $10.1039 / \times 0 \times x 00000 x$ www.rsc.org/

\section{Dinuclear Iridium and Rhodium Complexes with Bridging Arylimidazolide- $N^{3}, C^{2}$ Ligands: Synthetic, Structural, Reactivity, Electrochemical and Spectroscopic Studies ${ }^{\dagger}$}

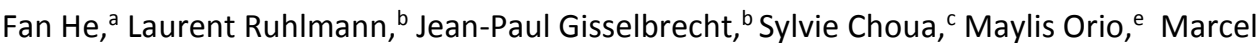 \\ Wesolek, ${ }^{a}$ Andreas A. Danopoulos, ${ }^{* a, d}$ Pierre Braunstein*a
}

\begin{abstract}
Deprotonation of 1-arylimidazoles (aryl = mesityl (Mes), 2,6-diisopropylphenyl (Dipp)), with $n$-butyl lithium afforded the corresponding derivatives (1-aryl-1H-imidazol-2-yl))ithium (1a, $\mathrm{Ar}=\mathrm{Mes} ; \mathbf{1} \mathbf{b}, \mathrm{Ar}=\mathrm{Dipp})$ in good yield. Reaction of $\mathbf{1 a}$ with 0.5 equiv. of $[\operatorname{Ir}(\operatorname{cod})(\mu-\mathrm{Cl})]_{2}$ yielded two geometrical isomers of a doubly $\mathrm{C} 2, \mathrm{~N} 3-$-bridged dinuclear complex $[\operatorname{Ir}(\operatorname{cod})\{\mu-$ $\mathrm{C}_{3} \mathrm{H}_{2} \mathrm{~N}_{2}$ (Mes)- $\left.\left.\kappa \mathrm{C} 2, \kappa N 3\right\}\right]_{2}(\mathbf{3}), \mathbf{3}_{\mathrm{H}-\mathrm{H}}$, a head-to-head $(\mathrm{H}-\mathrm{H})$ isomer of $C_{S}$ symmetry, and $\mathbf{3}_{\mathrm{H}-\mathrm{T}}$, the thermodynamically preferred head-to-tail ( $\mathrm{H}-\mathrm{T}$ ) isomer of $C_{2}$ symmetry. The metalated carbon of the 4 electron donor anionic bridging ligands has some carbene character, reminiscent of the situation in $\mathrm{N}$-metalated protic NHC complexes. Displacement of cod ligands from $\mathbf{3}_{\mathrm{H}-\mathrm{H}}$ and $\mathbf{3}_{\mathrm{H}-\mathrm{T}}$ afforded the tetracarbonyl complexes $\left[\operatorname{Ir}(\mathrm{CO}){ }_{2}\left\{\mu-\mathrm{C}_{3} \mathrm{H}_{2} \mathrm{~N}_{2}(\mathrm{Mes})-\kappa \mathrm{C} 2, \kappa \mathrm{N} 3\right\}\right]_{2} \mathbf{4}_{\mathrm{H}-\mathrm{H}}$ and $\mathbf{4}_{\mathrm{H}-\mathrm{T}}$, respectively. The reaction with $\mathrm{PMe}_{3}$, which gave only one complex, $\left[\operatorname{Ir}(\mathrm{CO})\left(\mathrm{PMe}_{3}\right)\left\{\mu-\mathrm{C}_{3} \mathrm{H}_{2} \mathrm{~N}_{2}(\mathrm{Mes})-\kappa \mathrm{C} 2, \kappa N 3\right\}\right]_{2}(5)$, demonstrates that the isomerization of the central core $\operatorname{Ir}\left[\mu-\mathrm{C}_{3} \mathrm{H}_{2} \mathrm{~N}_{2} \text { (Mes)- } \kappa \mathrm{K} 2,{ }_{2} \mathrm{NN} 3\right]_{2} \mathrm{Ir}$ from $\mathrm{H}-\mathrm{H}$ to $\mathrm{H}-\mathrm{T}$ on going from $4 \mathrm{H}-\mathrm{H}$ to 5 is readily triggered by phosphine substitution under mild conditions. Oxidative-addition of Mel to 5 afforded the formally metal-metal bonded $d^{7}-d^{7}$ complex $\left[I r_{2}(\mathrm{CO})_{2}\left(\mathrm{PMe}_{3}\right)_{2}(\mathrm{Me})\left\{\left\{\mu-\mathrm{C}_{3} \mathrm{H}_{2} \mathrm{~N}_{2}(\mathrm{Mes})-\kappa \mathrm{C} 2, \kappa N 3\right\}_{2}\right](6)\right.$. The blue $\left[\operatorname{Ir}\left(\mathrm{C}_{2} \mathrm{H}_{4}\right)_{2}\left\{\mu-\mathrm{C}_{3} \mathrm{H}_{2} \mathrm{~N}_{2}(\mathrm{Mes})-\kappa \mathrm{C} 2, \kappa \mathrm{N} 3\right\}\right]_{2}(7)$ and purple $\left[\mathrm{Rh}\left(\mathrm{C}_{2} \mathrm{H}_{4}\right)_{2}\left\{\mu-\mathrm{C}_{3} \mathrm{H}_{2} \mathrm{~N}_{2} \text { (Dipp) }-\kappa \mathrm{C} 2, \kappa \mathrm{N} 3\right\}\right]_{2}$ (9) tetraethylene complexes were also obtained with only a $\mathrm{H}-\mathrm{T}$ arrangement of the bridging ligands. Although only modestly efficient in alkane dehydrogenation, complex $\mathbf{7}$ was found to be a more active pre-catalyst than $\mathbf{3}_{\mathrm{H}-\mathrm{T}}, \mathbf{4}_{\mathrm{H}-\mathrm{T}}$ and $\mathbf{5}$, probably because of the favorable lability of the ethylene ligands. From cyclic voltammetry, exhaustive coulometry and spectroelectrochemistry studies, it was concluded that $\mathbf{3}_{\mathrm{H}-\mathrm{T}}$ undergoes a metalbased one electron oxidation to generate the mixed-valent $\operatorname{Ir}(I) / \operatorname{Ir}(I)$ system. The energy of the intervalence band for the orange dirhodium complex $\left[\mathrm{Rh}(\operatorname{cod})\left\{\mu-\mathrm{C}_{3} \mathrm{H}_{2} \mathrm{~N}_{2}\left(\text { Mes) }{ }_{k} \mathrm{~K} C 2,{ }_{k} \mathrm{~N} 3\right\}\right]_{2}(\mathbf{8})\right.$ is shifted toward lower energies in comparison with $\mathbf{3}_{\mathrm{H}}$ $\tau$, reflecting the decrease of the energy with the intermetallic distance. It was concluded from the EPR study that the Ir and Rh centres contribute substantially to the experimental magnetic anisotropy and thus to the singly occupied molecular orbital (SOMO) in the mixed-valent $\operatorname{Ir}(\mathrm{I}) / \mathrm{Ir}(\mathrm{II})$ and $\mathrm{Rh}(\mathrm{I}) / \mathrm{Rh}(\mathrm{II})$ systems. The molecular structures of $\mathbf{3}_{\mathrm{H}-\mathrm{H}}, \mathbf{3}_{\mathrm{H}-\mathrm{T}, \mathbf{8}}$ and $\mathbf{9}$ were
\end{abstract}

\footnotetext{
a. Laboratoire de Chimie de Coordination, Institut de Chimie (UMR 7177 CNRS), Université de Strasbourg, 4 rue Blaise Pascal, 67081 Strasbourg Cedex (France). Email: braunstein@unistra.fr

b. Laboratoire d'Electrochimie et de Chimie Physique du Corps Solide, Institut de Chimie (UMR 7177 CNRS), Université de Strasbourg, 4 rue Blaise Pascal, 67081 Strasbourg Cedex (France). E-mail: danopoulos@unistra.fr

. Institut de Chimie, Université de Strasbourg, 1 rue Blaise Pascal, BP 296 R8, F67008 Strasbourg, Cedex (France).

d. Université de Strasbourg, Institute for Advanced Study (USIAS), Strasbourg (France).

e. Aix Marseille Université, CNRS, Centrale Marseille, ISM2 UMR 7313,

13397 Marseille (France).

†Electronic Supplementary Information (ESI) available: Table S1 contains the crystal data for $\mathbf{3}_{\mathrm{H}-\mathrm{H}}, \mathbf{3}_{\mathrm{H}-\mathrm{T}}, \mathbf{8}$ and $\mathbf{9}$ (CCDC 1052655-1052658), Figures giving details of cyclic voltammograms (S1 and S2), UV-visible-NIR absorption spectra (S3 and S4), ${ }^{1} \mathrm{H}$ NMR spectra (S5 and S6), EPR spectra (S7), optimized structure (S8), spin population distribution and SOMO (S9). For ESI and crystallographic data in CIF or other electronic format see DOI: 10.1039/x0xx00000x
} 
determined by X-ray diffraction.

\section{Introduction}

The isolation by Arduengo and co-workers of stable $\mathrm{N}$ heterocyclic carbenes (NHCs) of the imidazole type with bulky $\mathrm{N}$-substituents, ${ }^{1}$ has triggered a fast growing interest for this class of ligands, in particular in organometallic chemistry. ${ }^{2}$ Protic NHCs (pNHCs) are characterised by the presence of a Nbound $\mathrm{H}$ atom and have been comparatively much less investigated, despite their strong $\sigma$-donor character and the possibility for the $\mathrm{NH}$ group to be involved in secondary interactions of potential relevance to bifunctional catalysis, ${ }^{3}$ substrate recognition ${ }^{4}$ and biological systems. ${ }^{5}$

Different synthetic methodologies allow access to pNHC metal complexes: building the $\mathrm{C}$-bound heterocycle in the metal coordination sphere, ${ }^{6}$ using suitable $\mathrm{N}$-protecting groups that are removed after metal coordination, ${ }^{7}$ or facilitating the kinetic formation of the $\mathrm{M}-\mathrm{C}_{\mathrm{NHC}}$ bond by the oxidativeaddition of the $\mathrm{C}-\mathrm{X}$ bond of halo-imidazoles ( $\mathrm{X}=$ halide). ${ }^{8}$ Most recently, we found that $N$-arylimine-functionalized pNHC $\operatorname{Ir}(\mathrm{I})$ and $\operatorname{Ir}(\mathrm{III})$ complexes could be readily obtained from cationic or neutral $\operatorname{Ir}(\mathrm{I})$ imidazole complexes using excess $\mathrm{TIPF}_{6}$ or $[\operatorname{Ir}(\operatorname{cod})(\mu-\mathrm{Cl})]_{2}$, respectively. ${ }^{9}$ Deprotonation of such a $\mathrm{pNHC}$ $\operatorname{Ir}(\mathrm{I})$ complex was shown to give rise to an equilibrium between a mononuclear complex containing a C-bound 'anionic' imidazolide and its dimer in which this moiety binds in a $\mu-C, N$ bridging mode (Scheme 1). ${ }^{9}$

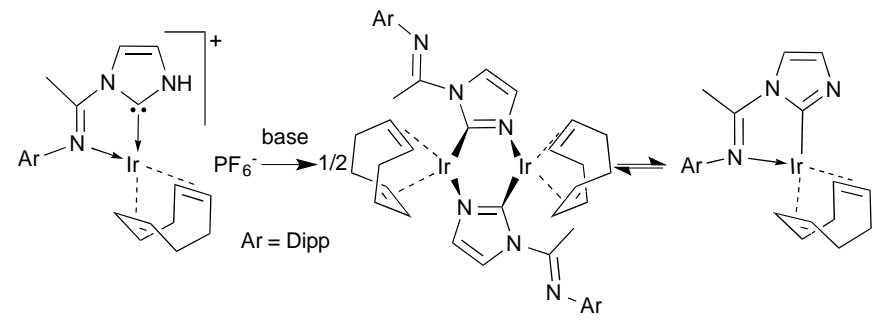

Scheme 1 Deprotonation of a protic NHC (pNHC) Ir(I) complex leading to an equilibrium between a mononuclear complex containing a C-bound 'anionic' imidazolide and its dimer. ${ }^{9}$

Anionic imidazolides possess interesting properties. Lithium 1-methyl-(4-t-butyl)imidazolide was found by Boche and coworkers to have carbene character, as supported by the ${ }^{13} \mathrm{C}$ NMR chemical shift of its C2 atom ( $\delta$ 195.9) and an X-ray diffraction study. ${ }^{10}$ Kostyuk and co-workers reported a method to synthesize $\mathrm{N}$-phosphorylated carbenes by the reaction between lithium imidazolides, bearing a bulky $\mathrm{N}$-bound $t$-butyl or adamantyl group, and di(t-butyl)chlorophosphine. ${ }^{11}$ Furthermore, an imidazolide can act as a N,C-bidentate ligand, comparable to a pyrazolide. While dinuclear bis $(\mu-$ pyrazolido)iridium(I) complexes have been widely investigated in oxidative addition reactions, ${ }^{12}$ substitution chemistry, ${ }^{13}$ kinetic $^{14}$ and theoretical studies, ${ }^{15}$ no extensive study on dinuclear iridium complexes bearing imidazolides has yet been carried out. ${ }^{16}$ A brief report described in 1983 the synthesis of dinuclear imidazolide $\mathrm{Rh}(\mathrm{I})$ complexes by deprotonation with MeLi of a mononuclear imidazole complex. ${ }^{17}$ As part of our current investigations on the tautomerism/metallotropism between $\mathrm{pNHC}$ and imidazole ligands in iridium complexes (Scheme 2), ${ }^{9}$ we describe herein the synthesis, structural and spectroscopic characterisation, reactivity and electrochemical properties of a series of doubly $\mathrm{C}, \mathrm{N}$-bridged dinuclear iridium and rhodium complexes bearing 1-arylimidazolide ligands.<smiles></smiles>

Scheme 2 Tautomerism/metallotropism between pNHC and imidazole ligands. ${ }^{9}$

\section{Results and discussion}

Synthesis and characterisation of the di-iridium complexes.

Starting from 1-arylimidazoles (aryl = mesityl (Mes), 2,6diisopropylphenyl (Dipp)), the corresponding derivatives (1aryl-1H-imidazol-2-yl)lithium ( $1 \mathrm{a}, \mathrm{Ar}=\mathrm{Mes} ; 1 \mathrm{~b}, \mathrm{Ar}=\mathrm{Dipp}$ ) were prepared in good yield by deprotonation with a stoichiometric amount of $n$-butyl lithium in pentane at $-30{ }^{\circ} \mathrm{C}$ (Scheme 3 ).

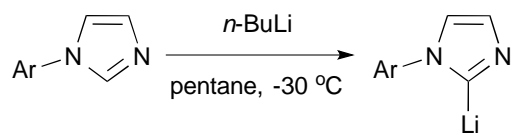

1a $\mathrm{Ar}=$ Mes, yield $70 \%$

1b $\mathrm{Ar}=\mathrm{Dipp}$, yield $92 \%$

Scheme 3 Synthesis of (1-aryl-1H-imidazol-2-yl)lithium (1a,b).

In their NMR spectra in THF- $\mathrm{d}_{8}$, the absence of the ${ }^{1} \mathrm{H}$ NMR resonance of the proton at $\mathrm{C} 2$ and the values of ${ }^{13} \mathrm{C}\left\{{ }^{1} \mathrm{H}\right\} \mathrm{NMR}$ resonance due to the $\mathrm{C} 2$ carbon, at $\delta 205.8$ for (1-mesityl- $1 H$ imidazol-2-yl)lithium (1a) and $\delta$ ?]202.3 for (1-(2,6diisopropylphenyl)- $1 \mathrm{H}$-imidazol-2-yl)lithium (1)), consistent with the metallation of this carbon.
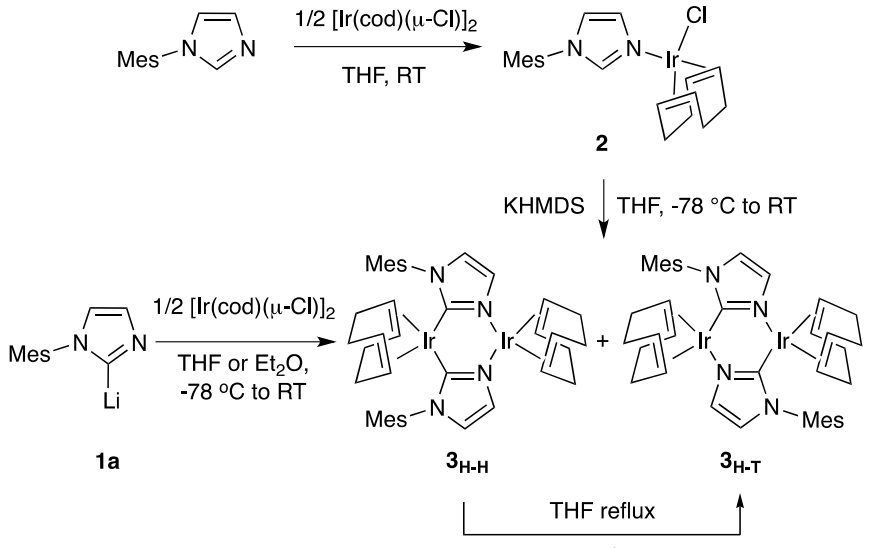

$24 \mathrm{~h}$ 
Scheme 4 Stepwise or direct synthesis of the two isomers of the dinuclear complexes $\mathbf{3}_{\mathrm{H}-\mathrm{H}}$ and $\mathbf{3}_{\mathrm{H}-\mathrm{T}}$.

Treatment of $1 \mathrm{a}$ with 0.5 equiv. of $[\operatorname{Ir}(\operatorname{cod})(\mu-\mathrm{Cl})]_{2}$ at $-78{ }^{\circ} \mathrm{C}$ in THF led to the formation of the doubly $\mathrm{C}, \mathrm{N}$-bridged dinuclear complex $\left[\operatorname{lr}(\operatorname{cod})\left\{\mu-\mathrm{C}_{3} \mathrm{H}_{2} \mathrm{~N}_{2} \text { (Mes) }-\kappa \mathrm{C} 2, \kappa \mathrm{N} 3\right\}\right]_{2}$ (3) as a red solid in nearly quantitative yield (Scheme 4). Its ${ }^{1} \mathrm{H}$ and ${ }^{13} \mathrm{C}\left\{{ }^{1} \mathrm{H}\right\}$ NMR spectra in $\mathrm{C}_{6} \mathrm{D}_{6}$ revealed the presence of a ca. 40:60 mixture of two constitutional isomers, $\mathbf{3}_{\mathrm{H}-\mathrm{H}}$, a head-to-head isomer of $C_{\mathrm{S}}$ symmetry, and $\mathbf{3}_{\mathrm{H}-\mathrm{T}}$, a head-to-tail isomer of $C_{2}$ symmetry. In the NMR spectra of the mixture in $\mathrm{C}_{6} \mathrm{D}_{6}$, each isomer displays one set of mesityl, imidazolide and cod signals. The chemical shifts of the ${ }^{13} \mathrm{C}\left\{{ }^{1} \mathrm{H}\right\}$ NMR resonance due to the $\mathrm{C} 2$ carbon $(\delta$ 171.3 and 172.0) are considerably upfield-shifted when compared to the value of $205.8 \mathrm{ppm}$ in $\mathbf{1 a}$. It turned out to be difficult to efficiently separate and isolate each isomer pure out of this mixture because of their similar solubility properties. Another procedure to prepare doubly $\mathrm{C}, \mathrm{N}$-bridged dinuclear complexes was found to consist of the deprotonation of 1-mesitylimidazolyl(cycloocta-1,5diene)iridium(I) chloride [ $\operatorname{Ir}(\mathrm{cod}) \mathrm{Cl}\left\{\mathrm{C}_{3} \mathrm{H}_{3} \mathrm{~N}_{2}\right.$ (Mes)- $\left.\left.\kappa \mathrm{N} 3\right\}\right]$ (2) with a stoichiometric amount of potassium bis(trimethylsilyl)amide (KHMDS) in THF at $-78^{\circ} \mathrm{C}$. According to the NMR spectra, a ca. 40:60 mixture of the same two isomers $\mathbf{3}_{\mathrm{H}-\mathrm{H}}$ and $\mathbf{3}_{\mathrm{H}-\mathrm{T}}$ was again obtained. However, when the reaction using 1a was repeated in $\mathrm{Et}_{2} \mathrm{O},{ }^{16 \mathrm{~b}}$ the resulting red suspension was found to consist of a ca. 90:10 mixture of $\mathbf{3}_{\mathrm{H}-\mathrm{H}}$ and $\mathbf{3}_{\mathrm{H}-\mathrm{T}}$, after dissolution in toluene and ${ }^{1} \mathbf{H}$ NMR analysis. This difference in proportions obtained in THF is likely due to the lower solubility of $\mathbf{3}_{\mathbf{H}-\mathrm{H}}$ in $\mathrm{Et}_{2} \mathrm{O}$. After recrystallization from a toluene/ $\mathrm{Et}_{2} \mathrm{O}$ solution at $30{ }^{\circ} \mathrm{C}$, deep red crystals of one pure isomer were obtained in $80 \%$ yield. In its ${ }^{1} \mathrm{H}$ NMR spectrum $\left(\mathrm{C}_{6} \mathrm{D}_{6}\right)$, the $\mathrm{C} 4$ and $\mathrm{C} 5$ imidazolyl protons positions gave rise to an $A X$ pattern at $\delta$ $7.20(\mathrm{~d})$ and $6.42\left(\mathrm{~d},{ }^{3} \mathrm{~J}=1.4 \mathrm{~Hz}\right)$. In the ${ }^{13} \mathrm{C}\left\{{ }^{1} \mathrm{H}\right\}$ NMR spectrum, the three resonances at $\delta 171.3,125.5$ and 122.4 are assigned to the C2, C4 and C5 imidazolyl carbons, respectively. However, a definitive assignment of this isomer as $\mathrm{H}-\mathrm{H}$ or $\mathrm{H}-\mathrm{T}$ arrangement was impossible on the exclusive basis of the spectroscopic data. Fortunately, its structure was elucidated by X-ray diffraction analysis and established its $\mathrm{H}-\mathrm{H}$ arrangement. The molecular structure of $\mathbf{3}_{\mathrm{H}-\mathrm{H}}$ is shown in Fig. 1 , with selected bond lengths and angles. The $C_{\mathrm{s}}$ molecular symmetry of the complex in solution is almost retained in the solid state, as indicated by NMR spectroscopy. The boat conformation of $\mathbf{3}_{\mathrm{H}-\mathrm{H}}$ is similar to that of the analogous bridged pyrazolido complex. ${ }^{12 \mathrm{~b}}$ There is no direct iridium-iridium interaction,the separation between the metal atoms being 3.1844(9) A. The iridium(I) centres adopt an approximate square planar coordination geometry, defined by two olefinic bonds of the 1,5-cyclooctadiene ligand and two carbon atoms (or two nitrogen atoms) from the imidazolide bridging ligands. The latter can be formally considered as 4 electron anionic donors toward $\operatorname{Ir}(\mathrm{I})$ centres. The electronic arrangement at the metals is unsymmetrical and $\operatorname{Ir}(1)$ is more electron-rich than $\operatorname{Ir}(2)$ since it is bound to two carbanionic donors. The C1-N1

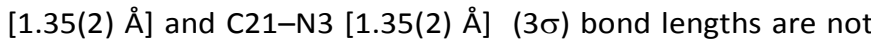
significantly shorter than those of C1-N2 [1.38(2) $\AA]$ and C21-
N4 $[1.39(2) \AA]$. This is indicative of electronic delocalization between the N1, C1 and N2 atoms (N3, C21 and N4, respectively) and of a carbene character for $\mathrm{C} 1$ and $\mathrm{C} 21$, respectively (Scheme 5).

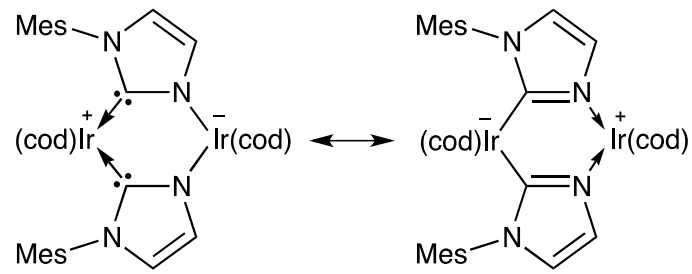

Scheme 5 Limiting resonance structures for the diiridium(l) complex $\mathbf{3}_{\mathrm{H}-\mathrm{H}}$ emphasising the dipolar nature of this isomer.

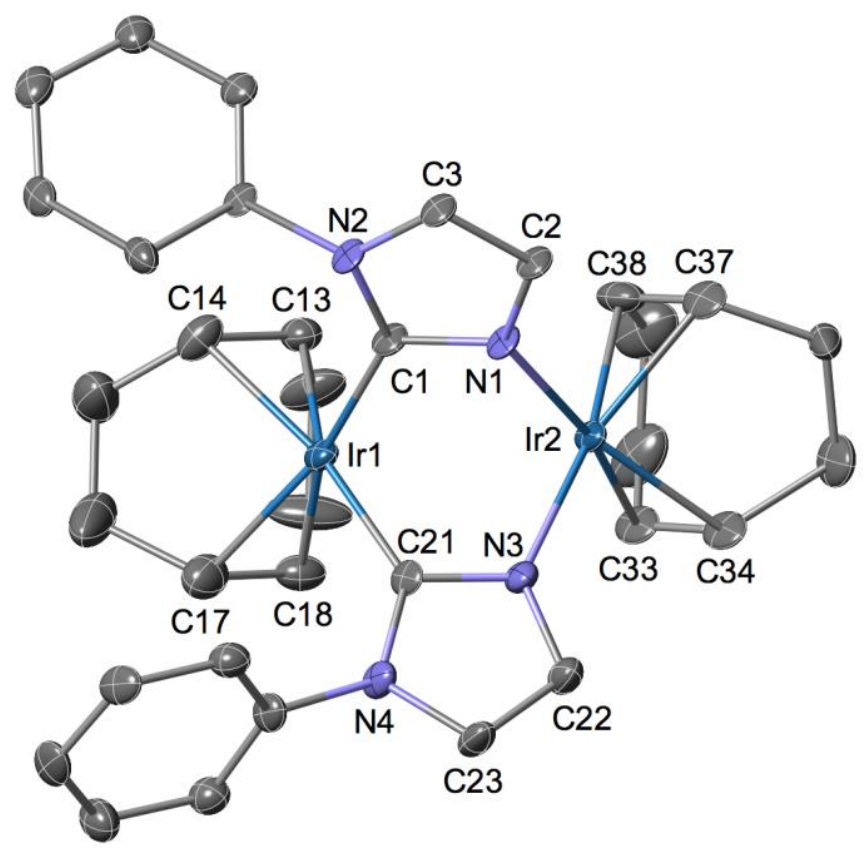

Fig. 1 Molecular structure of $\mathbf{3}_{\mathrm{H}-\mathrm{H}} \mathrm{H}$ atoms and methyl groups are omitted for clarity. Thermal ellipsoids are at the $30 \%$ level. Selected bond lengths $(\AA)$ and angles $\left({ }^{\circ}\right)$ : Ir1‥|r2 3.1844(9), C1-N1 1.35(2), C1-N2 1.38(2), Ir1-C1 2.05(1), Ir1-C21 2.05(1), Ir1C13 2.14(1), Ir1-C14 2.18(1), Ir1-C17 2.17(2), Ir1-C18 2.16(2), C13-C14 1.38(2), C17C18 1.36(3), C21-N3 1.35(2), C21-N4 1.39(2), Ir2-N1 2.07(1), Ir2-N3 2.06(1), Ir2-C33 2.10(1), Ir2-C34 2.09(1), Ir2-C37 2.11(2), Ir2-C38 2.10(2), C33-C34 1.39(3), C37-C38 1.40(3); N1-C1-N2 106(1), N3-C21-N4 105(1), C1-Ir1-C21 87.4(6), C13-Ir1-C14 37.2(6), C14-Ir1-C17 80.6(7), C17-Ir1-C18 36.5(7), C18-Ir1-C13 81.4(6), N1-Ir2-N3 86.5(5), C33-Ir2-C34 38.7(7), C34-Ir2-C37 82.8(6), C37-Ir2-C38 38.7(7), C38-Ir2-C33 $81.3(7)$

The whole complex $\mathbf{3}_{\mathrm{H}-\mathrm{H}}$ can be thermally converted to its isomer $\mathbf{3}_{\mathrm{H}-\mathrm{T}}$ upon refluxing a THF solution for $24 \mathrm{~h}$ (Scheme 4). In the ${ }^{1} \mathrm{H}$ NMR spectrum of $\mathbf{3}_{\mathrm{H}-\mathrm{T}}$ in $\mathrm{C}_{6} \mathrm{D}_{6}$, the protons at the imidazolide backbone carbons $\mathrm{C} 4$ and $\mathrm{C} 5$ give rise to an $\mathrm{AX}$ pattern at $\delta 7.02(\mathrm{~d})$ and $6.09\left(\mathrm{~d},{ }^{3} \mathrm{~J}=1.6 \mathrm{~Hz}\right)$. In the ${ }^{13} \mathrm{C}\left\{{ }^{1} \mathrm{H}\right\}$ NMR spectrum, the resonances at $\delta$ ? 125.4 and 121.3 are assigned to $\mathrm{C} 4$ and $\mathrm{C} 5$, respectively. The ${ }^{13} \mathrm{C}\left\{{ }^{1} \mathrm{H}\right\} \mathrm{NMR}$ resonance of the imidazolide $\mathrm{C} 2$ carbon ( $\mathrm{C} 1$ and $\mathrm{C} 21$ in Fig. 2) in $\mathbf{3}_{\mathrm{H}-\mathrm{T}}\left(\delta\right.$ ?]172.0) is downfield shifted compared to that in $\mathbf{3}_{\mathrm{H}-\mathrm{H}}$ ( $\delta$ ]171.3) (C1 and C21 in Fig. 1). Single crystals of $\mathbf{3}_{\mathrm{H}-\mathrm{T}}$ suitable 
for X-ray diffraction were obtained by slow diffusion of a layer of $\mathrm{Et}_{2} \mathrm{O}$ into a THF solution of $\mathbf{3}_{\mathrm{H}-\mathrm{T}}$ at room temperature under argon. The molecular structure of $\mathbf{3}_{\mathrm{H}-\mathrm{T}}$ is shown in Fig. 2, with selected bond lengths and angles.

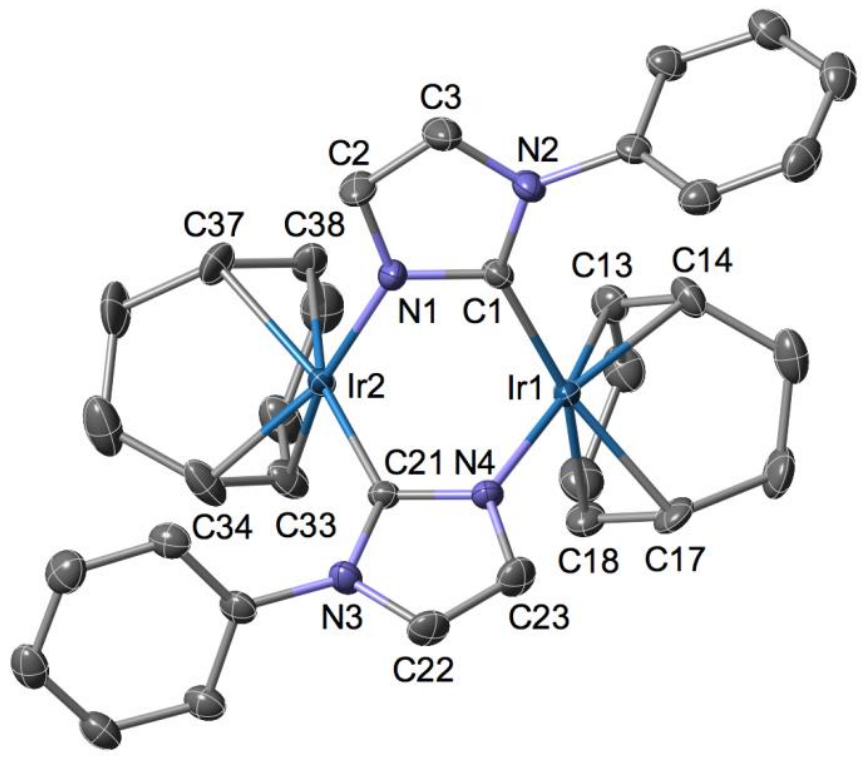

Fig. 2 Molecular structure of $\mathbf{3}_{\mathrm{H}-\mathrm{T}} \mathrm{H}$ atoms and methyl groups are omitted for clarity Thermal ellipsoids are at the $30 \%$ level. Selected bond lengths $(\AA)$ and angles $\left({ }^{\circ}\right)$ Ir1‥|r2 3.1407(2), C1-N1 1.349(5), C1-N2 1.373(5), Ir1-C1 2.058(4), Ir1-N4 2.068(3), Ir1-C13 2.121(4), Ir1-C14 2.112(4), Ir1-C17 2.166(4), Ir1-C18 2.158(4), C13-C14 1.409(6), C17-C18 1.390(6), C21-N3 1.378(5), C21-N4 1.335(5), Ir2-N1 2.067(3), Ir2C21 2.043(4), Ir2-C33 2.135(4), Ir2-C34 2.118(4), Ir2-C37 2.168(4), Ir2-C38 2.159(4), C33-C34 1.404(7), C37-C38 1.395(6); N1-C1-N2 106.1(3), N3-C21-N4 106.7(3), C1Ir1-N4 86.9(1), C13-Ir1-C14 38.9(2), C14-Ir1-C17 82.0(2), C17-Ir1-C18 37.5(2), C18Ir1-C13 81.2(2), N1-Ir2-C21 86.6(1), C33-Ir2-C34 38.6(2), C34-Ir2-C37 82.0(2), C37Ir2-C38 37.6(2), C38-Ir2-C33 81.2(2).

A boat conformation is observed for the structure of $\mathbf{3}_{\mathrm{H}-\mathrm{T}}$ similar to that of its isomer $\mathbf{3}_{\mathrm{H}-\mathrm{H}}$. The distance between two iridium atoms $\left(3.1407(2) \AA\right.$ ) is shorter than in $\mathbf{3}_{\mathbf{H}-\mathrm{H}}$ but still too long to represent a direct metal-metal interaction. Each iridium atom has a 16 valence electron configuration and adopts an approximate square planar coordination geometry, defined by two olefinic bonds of the 1,5-cyclooctadiene ligand, one carbon atom of one imidazolide and one nitrogen atom of the other bridging imidazolide ligand. The C1-N1 distance of
$1.349(5) \AA$ is only slightly shorter than C1-N2 1.373(5), likewise for C21-N4 1.335(5) compared to C21-N3 1.378(5), which would be consistent with a more pronounced double bond character for the $\mathrm{N}-\mathrm{C}$ bond in the bridging part of the ligands (Scheme 6).

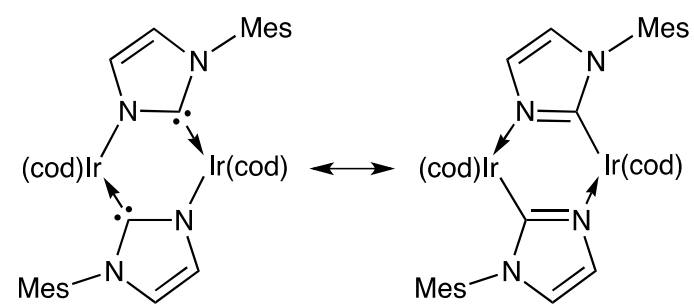

Scheme 6 Limiting resonance structures for $\mathbf{3}_{\mathrm{H}-\mathrm{T}}$, with a dominant contribution of the imidazolide form (right) to the actual structure.

\section{Displacement Reactions of the cod Ligands.}

With the original aim to prepare derivatives of $\mathbf{3}_{\mathrm{H}-\mathrm{H}}$ and $\mathbf{3}_{\mathrm{H}-\mathrm{T}}$ in which replacement of the cod ligands with two-electron donor ligands could modify the redox properties, as monitored by cyclic voltammetry, the tetracarbonyl derivatives $\left[\operatorname{Ir}(\mathrm{CO})_{2}\{\mu-\right.$

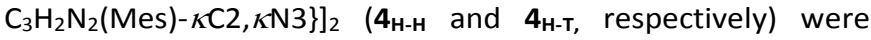
readily synthesized by reaction with carbon monoxide in $\mathrm{Et}_{2} \mathrm{O}$ (Scheme 7). While a clear brown $\mathrm{Et}_{2} \mathrm{O}$ solution of $\mathbf{4}_{\mathrm{H}-\mathrm{T}}$ was obtained, the reaction with $\mathbf{3}_{\mathrm{H}-\mathrm{H}}$ led to a yellow suspension. The higher solubility of $\mathbf{4}_{\mathrm{H}-\mathrm{T}}$ in $\mathrm{Et}_{2} \mathrm{O}$ compared to that of $\mathbf{4}_{\mathrm{H}-\mathrm{H}}$ is consistent with their different polarity. Indeed, $\mathbf{4}_{\mathrm{H}-\mathrm{T}}$ has a good solubility in nonpolar solvents such as pentane or $n$-hexane. The ${ }^{13} \mathrm{C}\left\{{ }^{1} \mathrm{H}\right\}$ NMR spectroscopic data for $\mathbf{4}_{\mathrm{H}-\mathrm{H}}$ and $\mathbf{4}_{\mathrm{H}-\mathrm{T}}$ in $\mathrm{C}_{6} \mathrm{D}_{6}$ show for each isomer one set of mesitylimidazolide and two CO signals, consistent with either a $C_{\mathrm{s}}$ or $C_{2}$ molecular symmetry. Compared to the cod precursors $\left(\mathbf{3}_{\mathrm{H}-\mathrm{H}}\right.$ and $\left.\mathbf{3}_{\mathrm{H}-\mathrm{T}}\right)$, the ${ }^{13} \mathrm{C}\left\{{ }^{1} \mathrm{H}\right\}$ NMR resonances of the imidazolide $\mathrm{C} 2$ are downfield shifted ( $\delta$ ? 172.8 in $\mathbf{4}_{\mathrm{H}-\mathrm{H}}$ and $\delta$ ? 175.1 in $\mathbf{4}_{\mathrm{H}-\mathrm{T}}$ ). The IR spectra of $\mathbf{4}_{\mathrm{H}-\mathrm{H}}$ and $\mathbf{4}_{\mathrm{H}-\mathrm{T}}$ show three $v(\mathrm{CO})$ bands at 2060, 2037, 1954 and 2059, 2041, $1968 \mathrm{~cm}^{-1}$, respectively, corresponding to the pattern for a dinuclear, folded tetracarbonyl framework. 

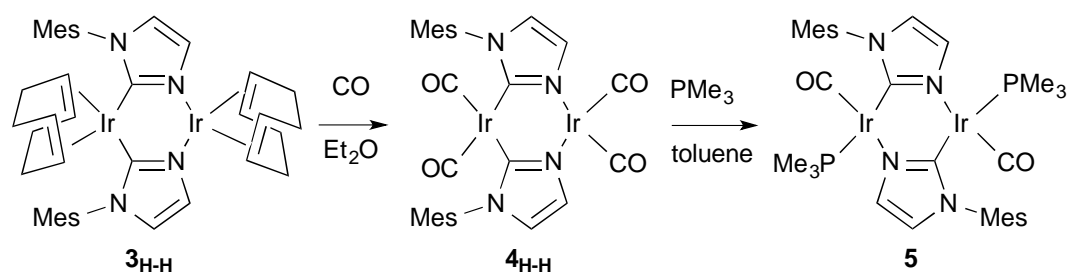

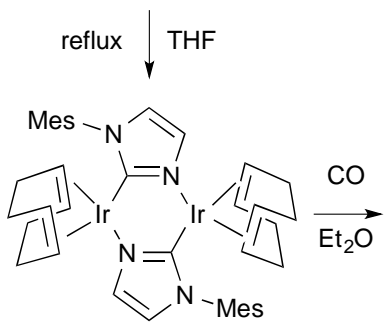

$3_{\mathrm{H}-\mathrm{T}}$

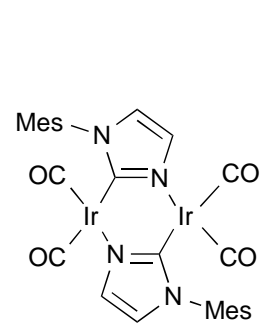

$\mathbf{4}_{\mathrm{H}-\mathrm{T}}$

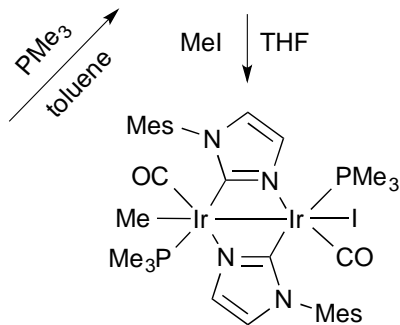

6

Scheme 7 Reactions of $\mathbf{3}_{\mathrm{H}-\mathrm{H}}$ and $\mathbf{3}_{\mathrm{H}-\mathrm{T}}$ with CO or $\mathrm{PMe}_{3}$.

The reaction of $\mathbf{4}_{\mathrm{H}-\mathrm{H}}$ or $\mathbf{4}_{\mathrm{H}-\mathrm{T}}$ with 2.0 equiv. of trimethylphosphine in toluene at room temperature afforded the same red solid $\left[\operatorname{Ir}(\mathrm{CO})\left(\mathrm{PMe}_{3}\right)\left\{\mu-\mathrm{C}_{3} \mathrm{H}_{2} \mathrm{~N}_{2} \text { (Mes) }-\kappa \mathrm{C} 2,{ } \kappa \mathrm{N} 3\right\}\right]_{2}$ (5), which shows two $v(\mathrm{CO})$ bands at 2000 and $1911 \mathrm{~cm}^{-1}$ in the infra-red spectrum (Scheme 7). According to the NMR spectra in $\mathrm{C}_{6} \mathrm{D}_{6}$, this complex contains one set of mesitylimidazolide, trimethylphosphine and $\mathrm{CO}$ signals. The imidazolide backbone protons at $\mathrm{C} 4$ and $\mathrm{C} 5$ are observed at $\delta 6.89(\mathrm{~d})$ and $6.68\left(\mathrm{~d},{ }^{3} \mathrm{~J}\right.$ $=0.9 \mathrm{~Hz}$ ) and the corresponding ${ }^{13} \mathrm{C}\left\{{ }^{1} \mathrm{H}\right\}$ NMR resonances at $\delta$ 128.3 and 120.1. In the ${ }^{13} \mathrm{C}\left\{{ }^{1} \mathrm{H}\right\}$ NMR spectrum, the resonances due to the $\mathrm{CO}$ and $\mathrm{C}_{\text {imidazolide }}$ carbons are found at $\delta 181.4\left(\mathrm{~d}, \mathrm{~J}_{\mathrm{C}-}\right.$ $\mathrm{p}=10.0 \mathrm{~Hz})$ and $177.1\left(\mathrm{~d}, J_{\mathrm{C}-\mathrm{p}}=112.0 \mathrm{~Hz}\right)$, respectively. The coordinated trimethylphosphine ligands give rise to a ${ }^{1} \mathrm{H} N M R$ resonance at $\delta 1.13\left(\mathrm{~d},{ }^{2} J_{\mathrm{H}-\mathrm{P}}=8.7 \mathrm{~Hz}\right)$, a ${ }^{13} \mathrm{C}\left\{{ }^{1} \mathrm{H}\right\} \mathrm{NMR}$ signal at $\delta$ ? $17.0\left(\mathrm{~d}, J_{\mathrm{C}-\mathrm{P}}=31.6 \mathrm{~Hz}\right)$ and a singlet in ${ }^{31} \mathrm{P}\left\{{ }^{1} \mathrm{H}\right\} \mathrm{NMR}$ at $\delta$ ? 24.1. All these data are consistent with a $C_{2}$ molecular symmetry for 5 , i.e. a H-T arrangement. The isomerization of the central core $\operatorname{Ir}\left[\mu-\mathrm{C}_{3} \mathrm{H}_{2} \mathrm{~N}_{2} \text { (Mes) }-\kappa \mathrm{C} 2, \kappa N 3\right]_{2}$ Ir from $\mathrm{H}-\mathrm{H}$ to $\mathrm{H}-\mathrm{T}$ on going from $\mathbf{4}_{\mathrm{H}-\mathrm{H}}$ to $\mathbf{5}$ has thus been triggered by phosphine substitution under mild conditions. The preference for the H-T arrangement is consistent with $\mathbf{3}_{\mathrm{H}-\mathrm{T}}$ being the thermodynamically favored isomer of $\mathbf{3}$.

\section{Oxidative-Addition of Mel.}

Treatment of $\mathbf{5}$ with a slight excess of Mel afforded a yellow product $\left[\mathrm{Ir}_{2}(\mathrm{CO})_{2}\left(\mathrm{PMe}_{3}\right)_{2}(\mathrm{Me}) \mid\left\{\mu-\mathrm{C}_{3} \mathrm{H}_{2} \mathrm{~N}_{2} \text { (Mes) }-\kappa \mathrm{C} 2, \kappa \mathrm{N} 3\right\}_{2}\right]$ (6) corresponding to a $1: 1$ addition product (Scheme 7). The observation in $\mathrm{C}_{6} \mathrm{D}_{6}$ of two sets of ${ }^{1} \mathrm{H}$ NMR signals for the mesitylimidazolide and trimethylphosphine protons and of ${ }^{13} \mathrm{C}\left\{{ }^{1} \mathrm{H}\right\}$ NMR signals for the CO ligands is consistent with a nonsymmetric system. In the ${ }^{13} \mathrm{C}\left\{{ }^{1} \mathrm{H}\right\}$ NMR spectrum, the resonances of the $\mathrm{C}_{\text {imidazolide }}$ carbons are significantly upfield shifted ( $\delta 142.8$ and 140.8 vs. $\delta 177.1$ in 5). The ${ }^{31} \mathrm{P}\left\{{ }^{1} \mathrm{H}\right\}$ NMR spectrum shows two close resonances at $\delta-46.6$ and -48.9 , consistent with similarly bonded but inequivalent phosphine ligands. ${ }^{12 a}$ Attempts to crystallize 6 were unsuccessful. The IR spectrum of 6 shows two $v(C O)$ bands at 2019 and $1952 \mathrm{~cm}^{-1}$, indicative of a smaller back-bonding from the metal to the $\mathrm{CO}$ ligands compared to $\mathbf{5}$ and consistent with the presence of iridium(II) centres in the formally metal-metal bonded 6 .

\section{Synthesis and Characterisation of Diiridium Tetraethylene Complexes}

Treatment of 1a with 0.5 equiv. $\left[\operatorname{Ir}\left(\mathrm{C}_{2} \mathrm{H}_{4}\right)_{2}(\mu-\mathrm{Cl})\right]_{2}$ at $-78{ }^{\circ} \mathrm{C}$ in $\mathrm{Et}_{2} \mathrm{O}$ led to the formation of the doubly $\mathrm{C}, \mathrm{N}$-bridged imidazolide dinuclear complex $\left[\operatorname{Ir}\left(\mathrm{C}_{2} \mathrm{H}_{4}\right)_{2}\left\{\mu-\mathrm{C}_{3} \mathrm{H}_{2} \mathrm{~N}_{2}\right.\right.$ (Mes)$\kappa \mathrm{C} 2, \kappa \mathrm{N} 3\}]_{2}(7)$ as a blue solid in $77 \%$ yield (Scheme 8 ).

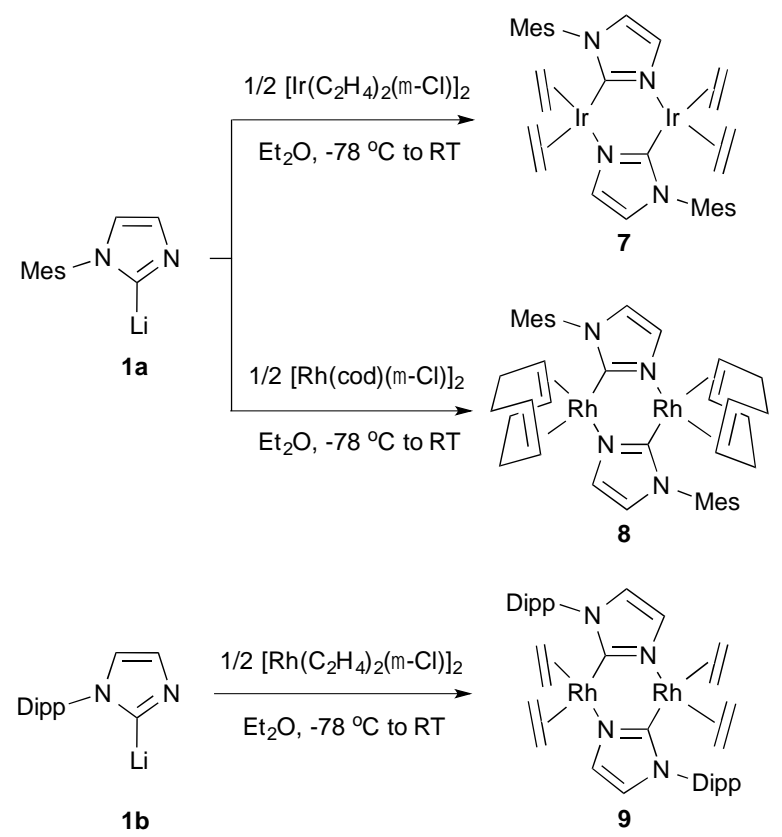

Scheme 8 Synthesis of the isolated dinuclear olefinic complexes 7-9.

The colour of $\mathbf{7}$ is similar to that of other tetraethylene diiridium complexes reported in the literature. ${ }^{13 c}$ Its NMR spectra in $\mathrm{C}_{6} \mathrm{D}_{6}$ only showed one set of mesitylimidazolide signals. In the ${ }^{13} \mathrm{C}\left\{{ }^{1} \mathrm{H}\right\} \mathrm{NMR}$ spectrum, the resonance of the 
$\mathrm{C}_{\text {imidazolide }}$ is observed at $\delta$ ? 171.5 . The imidazolide protons at $\mathrm{C} 4$ and $C 5$ gave rise to an $A X$ pattern at $\delta$ ]7.09 (d) and $6.49(\mathrm{~d}, 3 \mathrm{~J}=$ $1.5 \mathrm{~Hz}$ ) and the corresponding ${ }^{13} \mathrm{C}\left\{{ }^{1} \mathrm{H}\right\}$ NMR resonances occurred at $\delta$ ? 124.6 and 122.0 , respectively. In the ${ }^{1} \mathrm{H}$ NMR spectrum, two $A^{\prime}$ 'BB' $^{\prime}$ patterns are anticipated for the chemically- distinct coordinated ethylene ligands (trans to $C$ and trans to $\mathrm{N}$ ). ${ }^{13 c, 18}$ The resolution of the spectra did not allow to extract all the corresponding coupling constants. Nevertheless, one AA'BB' pattern with $\delta_{\boxminus} 3.13$ and $\delta_{\mathrm{A}} 2.89$ and

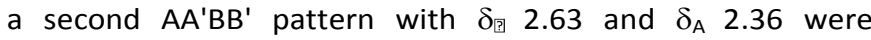
observed. ${ }^{19}$ Since the ${ }^{1} \mathrm{H}$ NMR chemical shifts of the mesityl and imidazolide groups are similar to those of $\mathbf{3}_{\mathrm{H}-\mathrm{T}}$, the arrangement of $\mathbf{7}$ should also be $\mathrm{H}$-T but attempts to crystallize 7 were unsuccessful.

\section{Synthesis and Characterisation of Dirhodium cod and Tetraethylene Complexes}

To extend the scope of the reactivity of $\mathbf{1 a}$, it was treated with 0.5 equiv. of $[\mathrm{Rh}(\operatorname{cod})(\mu-\mathrm{Cl})]_{2}$, and the new complex $[\mathrm{Rh}(\operatorname{cod})\{\mu-$ $\mathrm{C}_{3} \mathrm{H}_{2} \mathrm{~N}_{2}$ (Mes)- $\left.\left.\kappa \mathrm{C} 2, \kappa N 3\right\}\right]_{2}$ (8) was isolated (Scheme 8). As for 8, the ${ }^{13} \mathrm{C}\left\{{ }^{1} \mathrm{H}\right\}$ NMR spectrum of 8 in $\mathrm{C}_{6} \mathrm{D}_{6}$ only showed one set of mesitylimidazolyl signals and a doublet due to $\mathrm{C} 2$ at $176.2\left(\mathrm{~J}_{\mathrm{C}}\right.$ $\mathrm{Rh}=50.4 \mathrm{~Hz}$ ). The protons at $\mathrm{C} 4$ and $\mathrm{C} 5$ were observed in the ${ }^{1} \mathrm{H}$ NMR spectrum at $\delta 6.96$ and 6.51 as two broad singlets (the ${ }^{3} /_{\mathrm{H}-\mathrm{H}}$ coupling was not resolved) and the corresponding ${ }^{13} \mathrm{C}\left\{{ }^{1} \mathrm{H}\right\}$ resonances were found at $\delta 126.8$ and 120.3. Orange single crystals of $\mathbf{8}$ suitable for X-ray diffraction were grown from a toluene solution at $0{ }^{\circ} \mathrm{C}$ under argon. The molecular structure of $\mathbf{8}$ is shown in Fig. 3, with selected bond lengths and angles. This complex adopts a H-T arrangement and the same boat conformation like its iridium analog. The separation between the two Rh atoms is 3.2117(4) $\AA$, which is too long to represent a direct metal-metal interaction. Each rhodium atom is in a 16 valence electron configuration and adopts an approximate square planar geometry, defined by two olefinic bonds of the 1,5-cyclooctadiene ligand, one carbon atom of one imidazolide and one nitrogen atom of the another bridging imidazolide ligand.

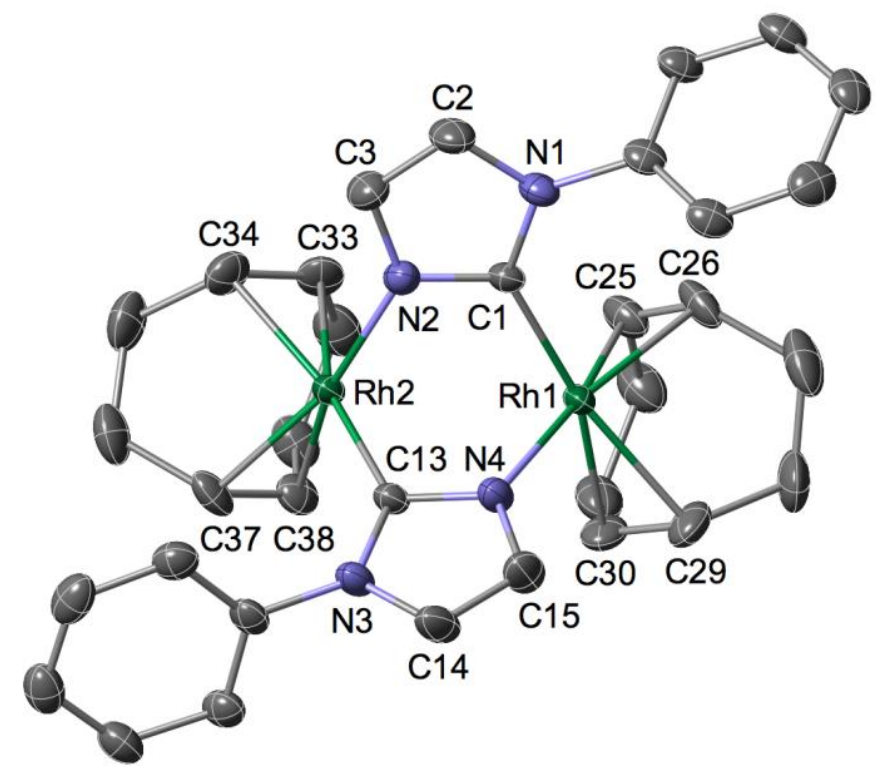

Fig 3 Molecular structure of $\mathbf{8}$. $\mathbf{H}$ atoms and methyl groups are omitted for clarity. Thermal ellipsoids are at the $30 \%$ level. Selected bond lengths $(\AA)$ and angles $\left({ }^{\circ}\right)$ : Rh1 ․ Rh2 3.2117(4), C1-N1 1.376(3), C1-N2 1.342(3), Rh1-C1 2.045(2), Rh1-N4 2.079(2), Rh1-C25 2.135(3), Rh1-C26 2.117(3), Rh1-C29 2.188(3), Rh1-C30 2.171(3), C25-C26 1.382(4), C29-C30 1.372(4), C13-N3 1.378(3), C13-N4 1.345(3), Rh2-N2 2.067(3), Rh2-C13 2.043(4), Rh2-C33 2.172(3), Rh2-C34 2.183(3), Rh2-C37 2.118(3), Rh2-C38 2.122(3), C33-C34 1.376(4), C37-C38 1.392(4); N1-C1-N2 106.7(2), N3-C13N4 106.3(2), C1-Rh1-N4 85.73(9), C25-Rh1-C26 37.9(1), C26-Rh1-C29 82.3(1), C29Rh1-C30 36.7(1), C30-Rh1-C25 81.4(1), N2-Rh2-C13 86.27(9), C33-Rh2-C34 36.8(1), C34-Rh2-C37 82.1(1), C37-Rh2-C38 38.3(1), C38-Rh2-C33 81.5(1).

The reaction of $\mathbf{1 b}$ with $\left[\mathrm{Rh}\left(\mathrm{C}_{2} \mathrm{H}_{4}\right)_{2}(\mu-\mathrm{Cl})\right]_{2}$ at $-78{ }^{\circ} \mathrm{C}$ in $\mathrm{Et}_{2} \mathrm{O}$ afforded $\left[\mathrm{Rh}\left(\mathrm{C}_{2} \mathrm{H}_{4}\right)_{2}\left\{\mu-\mathrm{C}_{3} \mathrm{H}_{2} \mathrm{~N}_{2} \text { (Dipp)- } \kappa \mathrm{C} 2, \kappa N 3\right\}\right]_{2}$ (9) (Scheme 8). Its NMR spectrum in $\mathrm{C}_{6} \mathrm{D}_{6}$ only showed one set of Dipp imidazolide signals and a doublet due to $\mathrm{C} 2$ at $175.1\left(\mathrm{~J}_{\mathrm{C}-\mathrm{Rh}}=\right.$ $49.0 \mathrm{~Hz}$ ). The resonances of the $\mathrm{H}$ atoms at the backbone carbons C4 and C5 were observed at $\delta 7.02$ and 6.64, respectively, as two singlets, and the corresponding ${ }^{13} \mathrm{C}\left\{{ }^{1} \mathrm{H}\right\}$ NMR resonances at $\delta 125.9$ and 122.8. In the ${ }^{1} \mathrm{H}$ NMR spectrum, like in 7, two AA'BB' patterns are anticipated for the chemically distinct coordinated ethylene ligands. ${ }^{13 c, 18}$ However, the resolution of the spectra did not allow extraction of all the corresponding coupling constants. Nevertheless one AA'BB' pattern with $\delta_{\text {日 }} 3.65$ and $\delta_{\mathrm{A}} 3.58$ and a second AA'BB' pattern with $\delta_{\text {曰 }} 2.86$ and $\delta_{\mathrm{A}} 2.62$ were observed. ${ }^{19}$ Purple single crystals of 9 suitable for X-ray diffraction were grown from $n$ hexane solution at $-30{ }^{\circ} \mathrm{C}$ under ethylene atmosphere. A similar reaction using $\mathbf{1 a}$ instead of $\mathbf{1 b}$ proceded similarly $\left({ }^{1} \mathrm{H}\right.$ monitoring) although a well-characterised solid product could not be obtained due to limited solubility in hexane from which $\mathbf{9}$ could be crystallised. The molecular structure of $\mathbf{9}$ is shown in Fig. 4, with selected bond lengths and angles. The structure of 9 adopts a boat conformation and like in $\mathbf{8}$, the arrangement of the bridging ligands is of the H-T type. The separation between two Rh atoms is 3.3146(9) $\AA$, which is again too long to represent a direct bonding interaction. Each 16 electron rhodium atom adopts an approximately square planar geometry, defined by two ethylene ligands, one carbon atom 
of one imidazolide and one nitrogen atom of the other bridging imidizolide ligand. Like in $\mathbf{3}_{\mathrm{H}-\mathrm{T}}$, the metrical data indicate a more pronounced double bond character for the $\mathrm{N}$ $\mathrm{C}$ bond located in the bridging part of the ligands.

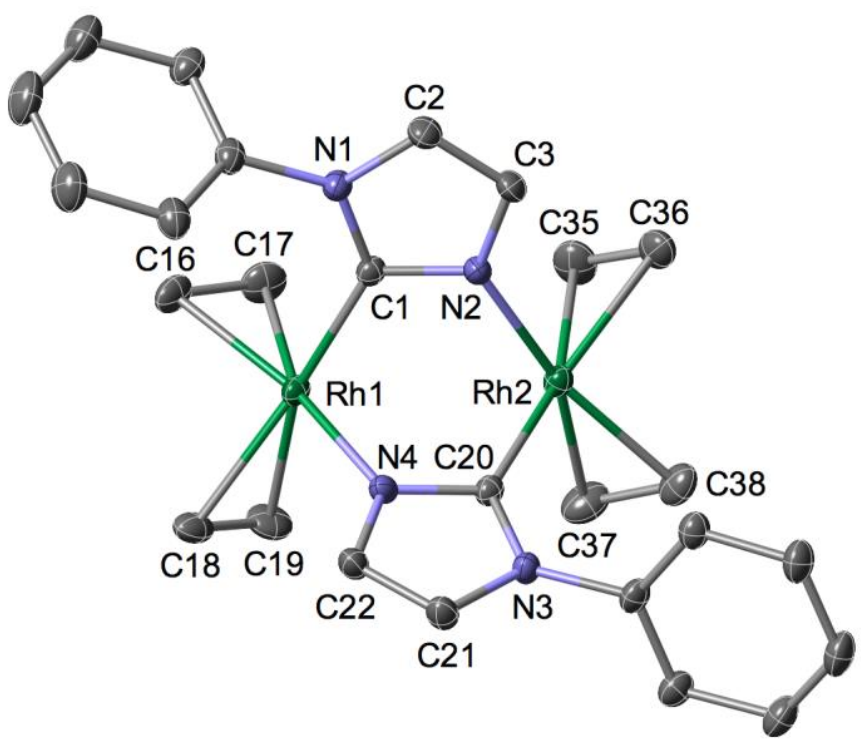

Fig. 4 Molecular structure of $\mathbf{9}$. $\mathbf{H}$ atoms and isopropyl groups are omitted for clarity. Thermal ellipsoids are at the $30 \%$ level. Selected bond lengths $(\AA)$ and angles $\left({ }^{\circ}\right)$ : Rh1 ․R R2 3.3146(9), C1-N1 1.372(3), C1-N2 1.344(3), Rh1-C1 2.040(3), Rh1-N4 2.081(2), Rh1-C16 2.141(3), Rh1-C17 2.125(3), Rh1-C18 2.208(3), Rh1-C19 2.192(3), C16-C17 1.369(5), C18-C19 1.351(5), C20-N3 1.379(3), C20-N4 1.342(3), Rh2-N2 2.080(2), Rh2-C20 2.041(3), Rh2-C35 2.202(3), Rh2-C36 2.211(3), Rh2-C37 2.129(3), Rh2-C38 2.124(3), C35-C36 1.354(5), C37-C38 1.385(5); N1-C1-N2 106.7(2), N3-C20N4 106.4(2), C1-Rh1-N4 84.6(1), C16-Rh1-C17 37.4(1), C17-Rh1-C19 89.2(2), C18Rh1-C19 35.8(1), C16-Rh1-C18 86.9(1), N2-Rh2-C20 84.9(1), C35-Rh2-C36 35.7(1), C36-Rh2-C38 87.0(1), C37-Rh2-C38 38.0(1), C35-Rh2-C37 89.1(2).

\section{Electrochemical investigations.}

We have shown above that the oxidative-addition of Mel to the diiridium $\mathrm{H}-\mathrm{T}$ complex $\mathbf{5}$ occurred at the dinuclear unit to give formally an $\operatorname{Ir}(\mathrm{II})-\operatorname{Ir}(\mathrm{II})$ complex rather than involving one metal centre to give a mixed-valence $\operatorname{Ir}(\mathrm{I}) / \mathrm{Ir}(\mathrm{III})$ complex. We thus became interested in studying of the redox behavior of representatives of these dinuclear complexes, in particular, with respect to the two possible $\mathrm{H}-\mathrm{T}$ or $\mathrm{H}-\mathrm{H}$ arrangements of the bridging ligands, which lead to a symmetrical or unsymmetrical electronic environmentof the metal centres, respectively. An electrochemical investigation of complexes $\mathbf{3}_{\mathrm{H}-}$ $\mathrm{T}$ and $\mathbf{8}$ was carried out by cyclic voltammetry and rotating disk voltammetry in $\mathrm{CH}_{2} \mathrm{Cl}_{2}+0.1 \mathrm{M}\left[n-\mathrm{Bu}_{4} \mathrm{~N}\right] \mathrm{PF}_{6}$. Cyclic voltammograms of the $\mathbf{3}_{\mathrm{H}-\mathrm{T}}$ and $\mathbf{8}$ with added ferrocene are presented in Figures S1 and S2 (see ESI) and show reversible processes. In contrast, irreversible oxidation was observed by cyclic voltammetry in the case of complex $\mathbf{3}_{\mathrm{H}-\mathrm{H}}$ (see Figure Sxxxx in ESI)

As shown in Fig. 5 and Table 1, two successive oxidations

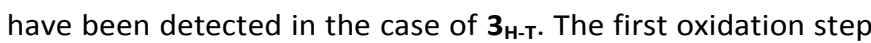
occurs at $-0.45 \mathrm{~V} v$ s. $\mathrm{Fc}^{+} / \mathrm{Fc}$ and corresponds to a reversible electron transfer, while the second step presents an irreversible oxidation peak at $+0.67 \mathrm{~V} v$ s. $\mathrm{Fc}^{+} / \mathrm{Fc}$.

The number of electrons exchanged during the first oxidation step was determined by exhaustive coulometry. During the electrolysis, the oxidation current decreased exponentially with time. When this current reached the residual value measured in the absence of electroactive material, typically after $4 \mathrm{~h}$ under the above conditions, the number of electrons transferred was $0.9 /$ molecule of $3_{\mathrm{H}-\mathrm{T}}$, which strongly suggests that oxidation of only one $\operatorname{Ir}(\mathrm{I})$ centre to $\operatorname{Ir}(\mathrm{II})$ has occurred, leading to the mixed-valent $\operatorname{Ir}(\mathrm{I}) / \operatorname{Ir}(\mathrm{II})$ intermediate. Attempts to chemically oxidize $\mathbf{3}_{\mathrm{H}-\mathrm{T}}$ using AgOTf in $\mathrm{CH}_{2} \mathrm{Cl}_{2}$ gave intractable mixture of species.

Table 1. Electrochemical data for $\mathbf{3}_{\mathrm{H}-\mathrm{T}}$ and $\mathbf{8} .^{\text {a }}$

$\begin{array}{ccc} & E_{1 / 2} \vee & \mathrm{Fc}^{+/ 0} \\ \text { Complex } & \text { non visible dans le pdf } & \text { non visible dans le pdf }\end{array}$

$\begin{array}{lll}\mathbf{3}_{\mathrm{H}-\mathrm{T}} & -0.45(64) & +0.67^{\mathrm{b}} \\ 8 & -0.40(63) & +0.58^{\mathrm{b}}\end{array}$

a All potentials in $\mathrm{V}$ vs. $\mathrm{Fc}^{+} / \mathrm{Fc}$ were obtained from cyclic voltammetry in $\mathrm{CH}_{2} \mathrm{Cl}_{2}$ containing $0.1 \mathrm{~mol}$ ? $\mathrm{L}^{-1}\left[n-\mathrm{Bu}_{4} \mathrm{~N}\right] \mathrm{PF}$. Scan rate $=0.1 \mathrm{~V} \mathrm{~s}^{-1}$. Working electrode: glassy carbon electrode. The given half-wave potentials in the case of the reversible couple are equal to $E_{1 / 2}=\left(E_{\mathrm{pa}}-E_{\mathrm{pc}}\right) / 2$. In bracket: $\left(\Delta E_{\mathrm{p}}\right.$, peak splitting in $\mathrm{mV}$ at a scan rate of $\left.0.1 \mathrm{Vs}^{-1}\right)$. ${ }^{\mathrm{b}}$ Irreversible electron transfer.

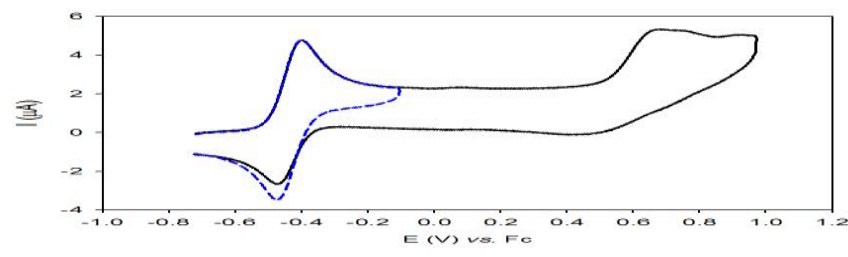

Fig. 5 Cyclic voltammograms of the $3_{\mathrm{H}-\mathrm{T}}\left(\mathrm{CH}_{2} \mathrm{Cl}_{2}+0.1 \mathrm{M}\left[n-\mathrm{Bu}_{4} \mathrm{~N}\right] \mathrm{PF}_{6}\right.$, glassy carbon electrode, scan rate $0.1 \mathrm{Vs}^{-1}$, vs. $\mathrm{Fc}^{+} / \mathrm{Fc}$ ).

In-situ spectroelectrochemical studies have been carried out, under argon atmosphere, to gain further insight into the nature of the electrogenerated species during this first reversible oxidation (Fig. 6). 

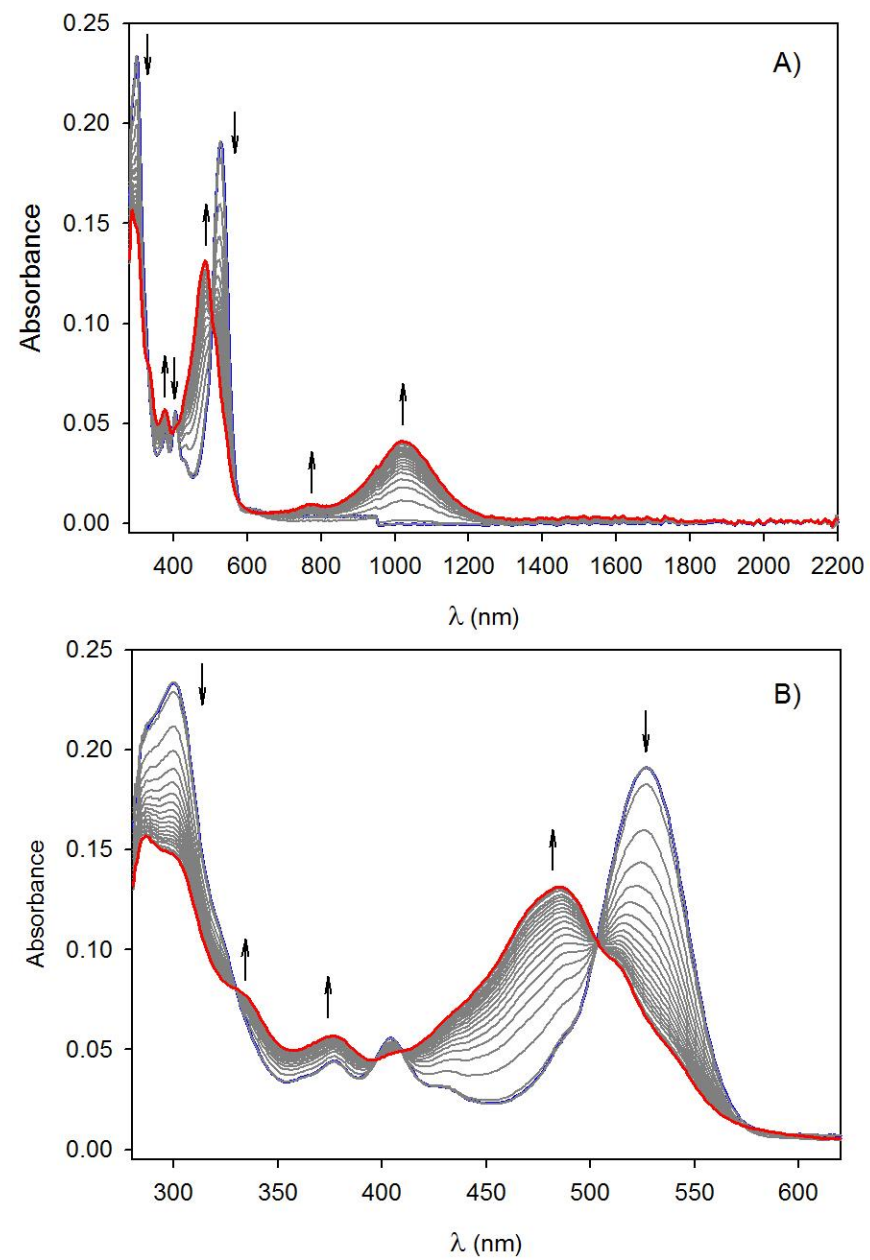

Fig. 6 A) Time-resolved UV-visible-NIR spectra of $\mathbf{3}_{\mathrm{H}-\mathrm{T}}$ for the first oxidation step (transition $\operatorname{Ir}(\mathrm{I}) / \mathrm{Ir}(\mathrm{I})$ to $\operatorname{Ir}(\mathrm{I}) / \operatorname{Ir}(\mathrm{II})$ ) in $\mathrm{CH}_{2} \mathrm{Cl}_{2}+0.1 \mathrm{M}\left[n-\mathrm{Bu}_{4} \mathrm{~N}\right] \mathrm{PF}_{6}$ (spectra recorded every $5 \mathrm{~s})$. B) UV-visible spectral evolution for the first oxidation step.

For $\mathbf{3}_{\mathrm{H}-\mathrm{T}}$, time resolved UV-Vis-NIR spectroelectrochemistry data were recorded during cyclic voltammetry between -0.70 $\mathrm{V}$ and $+0.20 \mathrm{~V} v s$. $\mathrm{Fc}^{+} / \mathrm{Fc}$ (scan rate $20 \mathrm{mVs}^{-1}$ ). As seen from the array of spectra depicted in Fig. 6, during the oxidation the generated $\operatorname{Ir}(\mathrm{I}) / \operatorname{Ir}(\mathrm{II})$ species is characterised by low-energy intervalence charge transfer (IVCT) bands in the near infrared region at $1024 \mathrm{~nm}$. On the reverse potential scan, a decrease of the intensity for this IVCT band was observed and the oxidized $\operatorname{Ir}(\mathrm{I}) / \operatorname{Ir}(\mathrm{II})$ system reverted quantitatively to the initial $\operatorname{Ir}(I) / \operatorname{Ir}(\mathrm{I})$ species.

From the results obtained by cyclic voltammetry (reversible oxidation at $-0.45 \vee v s$. $\mathrm{Fc}^{+} / \mathrm{Fc}$ ), exhaustive coulometry (oneelectron process) and spectroelectrochemistry (new NIR band at $\lambda_{\max }=1024 \mathrm{~nm}$ for the oxidized system), it can be concluded that $\mathbf{3}_{\mathrm{H}-\mathrm{T}}$ undergoes a one electron oxidation on the metal generating the mixed-valent $\operatorname{Ir}(I) / \operatorname{Ir}(I I)$ system, in equilibrium with $\operatorname{Ir}(\mathrm{II}) / \operatorname{Ir}(\mathrm{I})$, and giving rise to an IVCT band in the NIR region.

For comparison, we examined a $\mathrm{H}-\mathrm{T}$ dirhodium complex. Features similar to those for $\mathbf{3}_{\mathrm{H}-\mathrm{T}}$ were observed with $\mathbf{8}$ and the mixed-valent system $\mathrm{Rh}(\mathrm{I}) / \mathrm{Rh}(\mathrm{II})$. The cyclic voltammogram shows two successive oxidations, the first at $-0.40 \mathrm{~V} v \mathrm{~s}$. $\mathrm{Fc}^{+} / \mathrm{Fc}$ corresponds to a reversible electron transfer, while the second step is associated to an irreversible oxidation process at +0.58 $\mathrm{V} v$ s. $\mathrm{Fc}^{+} / \mathrm{Fc}$ (Fig. 7). Again, exhaustive coulometry indicated a number of electrons transferred of $0.9 /$ molecule for $\mathbf{8}$, leading to the mixed-valent intermediate $\mathrm{Rh}(\mathrm{I}) / \mathrm{Rh}$ (II).

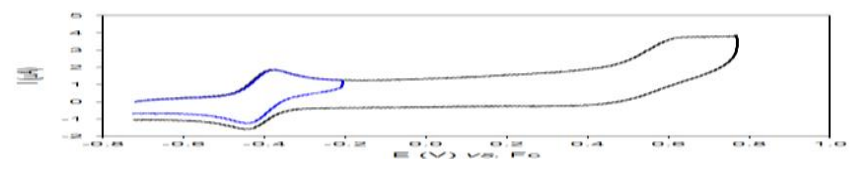

Fig. 7 Cyclic voltammograms of the $8\left(\mathrm{CH}_{2} \mathrm{Cl}_{2}+0.1 \mathrm{M}\left[n-\mathrm{Bu}_{4} \mathrm{~N}\right] \mathrm{PF} F_{6}\right.$, Glassy carbon electrode, scan rate $0.1 \mathrm{Vs}^{-1}$, vs. $\mathrm{Fc}^{+} / \mathrm{Fc}$ ).

Spectroelectrochemistry measurements at the first oxidation process evidenced a new high-energy intervalence charge transfer (IVCT) band around $1073 \mathrm{~nm}$, which is in good agreement with the formation of a mixed-valent intermediate $\mathrm{Rh}(\mathrm{I}) / \mathrm{Rh}$ (II) (Fig. 8). The new band at $612 \mathrm{~nm}$ might correspond to the $\mathrm{Rh}(\mathrm{II})$.

For 8 and for $\mathbf{3}_{\mathrm{H}-\mathrm{T}}$, we observed one additional band at 612 $\mathrm{nm}$ and $781 \mathrm{~nm}$, respectively. In studies on mixed-valent $\operatorname{Ir}(\mathrm{I}) / \operatorname{Ir}(\mathrm{II})$ or $\mathrm{Rh}(\mathrm{I}) / \mathrm{Rh}(\mathrm{II})$ intermediates, similar bands were also observed, but not at the same wavelength, because of the presence of different ligands. ${ }^{20}$ Such bands may be attributed to the $\operatorname{Ir}(I I)$ or $\mathrm{Rh}$ (II) component of the complexes. 

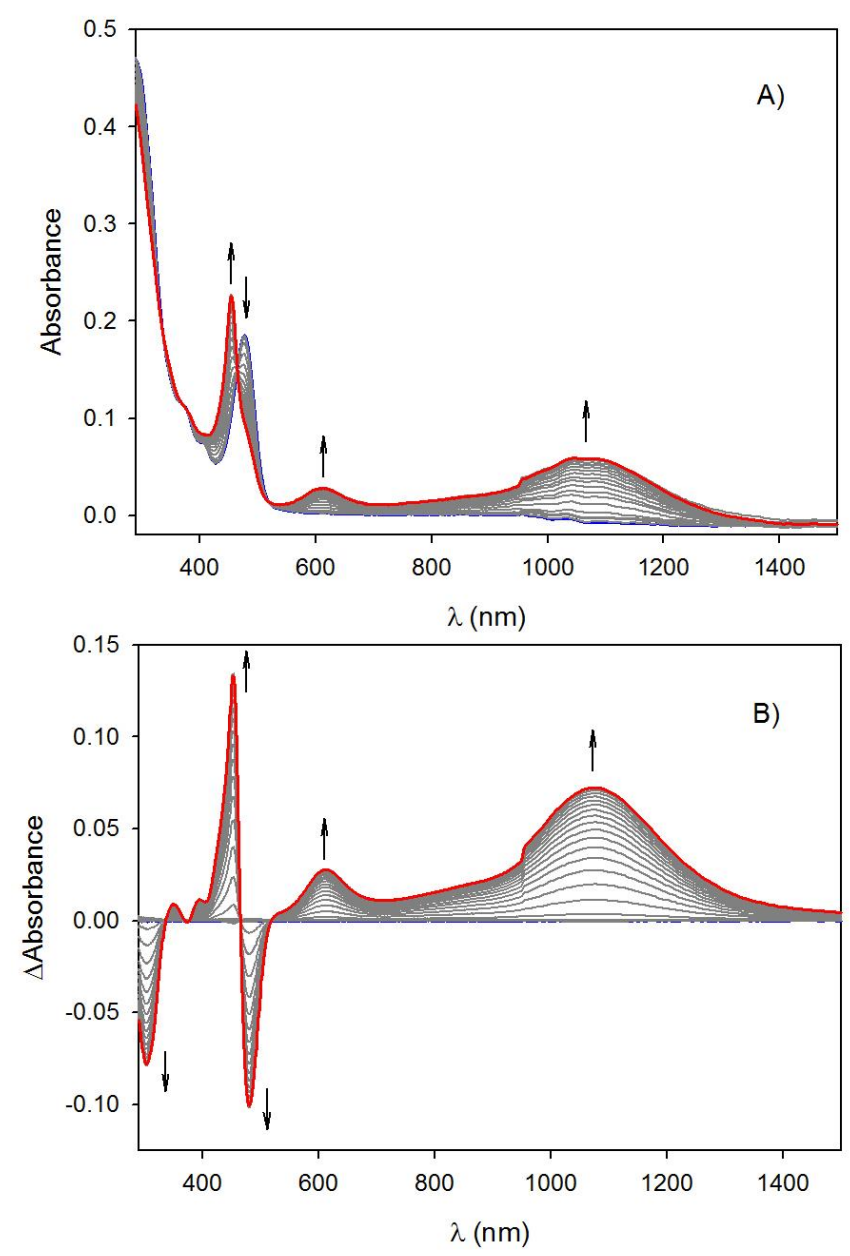

Fig. 8 A) Time-resolved UV-visible-NIR spectra of 8 for the first oxidation step (transition $\mathrm{Rh}(\mathrm{I}) / \mathrm{Rh}(\mathrm{I})$ to $\mathrm{Rh}(\mathrm{I}) / \mathrm{Rh}(\mathrm{II})$ ) in $\mathrm{CH}_{2} \mathrm{Cl}_{2}+0.1 \mathrm{M}\left[n-\mathrm{Bu}_{4} \mathrm{~N}\right] \mathrm{PF}_{6}$ (spectra recorded every $5 \mathrm{~s}$ ). B) Time-resolved UV-visible-NIR differential spectra for the first oxidation step.

For a dinuclear system, the electronic coupling calculated from the Hush equation ${ }^{21}$ decreases with the distance between the metal centers. Hush proposed that the electronic coupling could be extracted from the intervalence band shape according to eq (1):

$$
H_{\mathrm{ab}}=0.0206\left(\varepsilon_{\max } \Delta \mathrm{v}_{1 / 2} \lambda\right)^{1 / 2} / \mathrm{d}_{\mathrm{ab}}
$$

where $\varepsilon_{\max }\left(\mathrm{M}^{-1} \cdot \mathrm{cm}^{-1}\right)$ is the maximum intensity, $\Delta \mathrm{v}_{1 / 2}\left(\mathrm{~cm}^{-1}\right)$ is the width at half-height, $\lambda\left(\mathrm{cm}^{-1}\right)$ is the energy maximum band $\left(E_{o p}\right)$, and $d_{a b}(\AA)$ is the diabatic electron-transfer distance. $E_{o p}$ occurs at $9823 \mathrm{~cm}^{-1}\left(\lambda_{\max }=1018 \mathrm{~nm}\right)$ and at $9320 \mathrm{~cm}^{-1}\left(\lambda_{\max }=\right.$ $1073 \mathrm{~nm}$ ) for $\mathbf{3}_{\mathrm{H}-\mathrm{T}}$ and $\mathbf{8}$, respectively. Correspondingly, $\Delta \mathrm{v}_{1 / 2}$ are $47393 \mathrm{~cm}^{-1}$ and $40486 \mathrm{~cm}^{-1}$. According to eq (1), the corresponding calculated electronic couplings are $\mathrm{H}_{\mathrm{Ir}-\mathrm{Ir}}=3960$ $\mathrm{cm}^{-1}$ and $\mathrm{H}_{\mathrm{Rh}-\mathrm{Rh}}=4746 \mathrm{~cm}^{-1}$. Thus, the energy of the intervalence band for $\mathbf{8}$ is shifted toward lower energies in comparison with $\mathbf{3}_{\mathrm{H}-\mathrm{T}}$, reflecting the decrease of the energy with the intermetallic distance $\left(d_{\mathrm{Ir}-\mathrm{Ir}}=3.141 \AA\right.$, $\mathrm{d}_{\mathrm{Rh}-\mathrm{Rh}}=3.212$ Å).
The transition from charge localized to charge-delocalized (which are also called class II and class III, respectively, in the Robin-Day terminology) ${ }^{22}$ occurs at $\lambda=2 \mathrm{H}_{\mathrm{ab}}$, so mixed-valent (MV) compounds with $\lambda>2 \mathrm{H}_{\mathrm{ab}}$ are charge-localized and those with $\lambda<2 \mathrm{H}_{\mathrm{ab}}$ are charge-delocalized. In our case:

$3_{\mathrm{H}-\mathrm{T}}: \lambda\left(9823 \mathrm{~cm}^{-1}\right)>2 \mathrm{H}_{\mathrm{ab}}\left(2 \times 3960=7920 \mathrm{~cm}^{-1}\right)$

8: $\quad \lambda\left(9320 \mathrm{~cm}^{-1}\right)<2 \mathrm{H}_{\mathrm{ab}}\left(2 \times 4746=9492 \mathrm{~cm}^{-1}\right)$

For $8, \lambda\left(9320 \mathrm{~cm}^{-1}\right)$ is $\sim 2 \mathrm{H}_{\mathrm{ab}}$

These data thus suggest that $\mathbf{3}_{\mathrm{H}-\mathrm{T}}$ is a charge-localized while $\mathbf{8}$ is a charge-delocalized system under the conditions of our room temperature measurements.

\section{EPR measurements.}

EPR spectroscopy constitutes a highly suitable tool to evaluate the electronic structure of metal complexes with unpaired electrons, especially on heavy metal centres. At low temperature, the average $\langle g\rangle$ value and the anisotropy $(\Delta g)$ calculated from the principal values of the $g$-tensor afford a qualitative estimate of the extent of electron localization over the metal and/or over the ligand. ${ }^{23}$ We thus wanted to examine in more detail the electronic structure of the mixedvalent $\operatorname{Ir}(\mathrm{I}) / \mathrm{Ir}(\mathrm{II})$ and $\mathrm{Rh}(\mathrm{I}) / \mathrm{Rh}(\mathrm{II})$ species. The oxidized species were generated at room temperature by electrolysis after consumption of about 0.9 electron/molecule and the resulting solutions were transferred into an EPR tube under argon. The $X$-band EPR spectrum in frozen $\mathrm{CH}_{2} \mathrm{Cl}_{2}$ solution of $\operatorname{Ir}(\mathrm{I}) / \operatorname{Ir}$ (II) (the oxidized species of $\mathbf{3}_{\mathrm{H}-\mathrm{T}}$ ) exhibited a signal with an axial symmetry (Fig. 9) with $g_{1}=g_{2}=1.987$ and $g_{3}=2.123$ values (see Table 2). Increasing the temperature to ambient caused the EPR signal to disappear. In the case of the $\mathrm{Rh}(\mathrm{I}) / \mathrm{Rh}$ (II) system obtained by oxidation of $\mathbf{8}$, the EPR spectrum at low temperature displayed a rhombic signal (Fig. S7 in ESI). At room temperature, a very weak EPR signal is recorded with only one line centered at around $g=2.00$ without hyperfine structure. Satisfying simulations were obtained with one or two equivalent ${ }^{103} \mathrm{Rh}$ nucleus $(I=1 / 2$ isotopic abundance $100 \%$ ) and in order to discriminate between the two possibilities DFT calculations were performed. The structure of the $\mathrm{Rh}(\mathrm{I}) / \mathrm{Rh}(\mathrm{II})$ complex was subjected to geometry optimization (Fig. S8) and its electronic structure was investigated (Fig. S9). Mulliken population analysis indicates an equally distributed spin density between the two rhodium atoms with positive spin populations found at $\operatorname{Rh}(1)(0.49)$ and $\mathrm{Rh}(2)$ (0.49). The spin density of the Rh atoms accounts for $90 \%$ of the total spin density and the remaining $10 \%$ are spread over the ligands. The Singly Occupied Molecular Orbital (SOMO) of the complex displays $90 \% \mathrm{Rh}$ character and features the $\sigma$ antibonding interaction between the $R h 3 d_{z}^{2}$ orbitals. The EPR parameters arising from the spectral simulation for two equivalent ${ }^{103} \mathrm{Rh}$ nuclei are reported in Table 2. 
Table 2. EPR parameters of the oxidized complexes

\begin{tabular}{|c|c|c|c|c|c|c|c|c|}
\hline & $g_{1}$ & $g_{2}$ & $g_{3}$ & $<g>^{a}$ & $\Delta \mathrm{g}^{b}$ & 回国G & 回国G & 回国G \\
\hline $\operatorname{Ir}(I) / \operatorname{Ir}(I I)$ & 1.987 & 1.987 & 2.123 & 2.033 & 0.136 & - & - & - \\
\hline $\operatorname{Rh}(I) / \operatorname{Rh}(I I)$ & 1.993 & 2.031 & 2.105 & 2.043 & 0.112 & 33 & 18 & 27 \\
\hline
\end{tabular}

${ }^{a}\langle g\rangle=\left[\left(g_{1}{ }^{2}+g_{2}{ }^{2}+g_{3}{ }^{2}\right) / 3\right]^{1 / 2} ;{ }^{b} \Delta g=g_{3}-g_{1}$

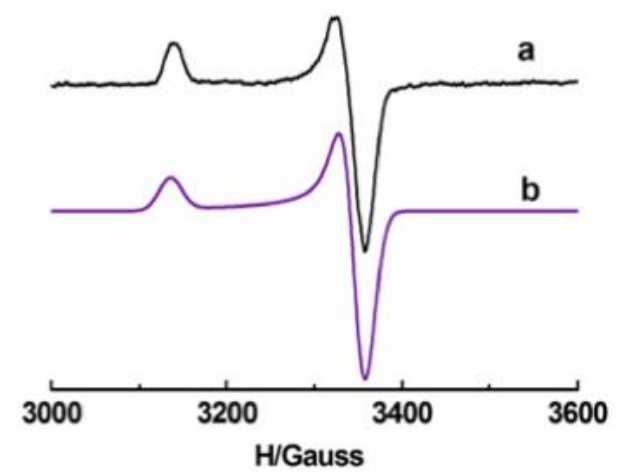

Fig. 9 EPR spectra of the $\operatorname{Ir}(\mathrm{I}) / \mathrm{Ir}(\mathrm{II})$ system electrochemically generated from $\mathbf{3}_{\mathrm{H}-\mathrm{T}}$ system electrochemically generated in $\mathrm{CH}_{2} \mathrm{Cl}_{2}$ at $100 \mathrm{~K}$ : a) Experimental spectrum b) Simulated spectrum.

The oxidized forms are characterised by a $g$ anisotropy and the average $g$ values are significantly larger than for the free electron (2.0023). Such features may imply that the Ir and Rh centres contribute substantially to the experimental magnetic anisotropy and thus to SOMO.

\section{Attempted catalytic transfer dehydrogenation of cyclooctane using iridium complexes $\mathbf{3}_{\mathrm{H}-\mathrm{T}}, \mathbf{4}_{\mathrm{H}-\mathrm{T}}, \mathbf{5}$ and $\mathbf{7}$ as precatalysts.}

Iridium pincer complexes have shown very promising catalytic properties in alkane dehydrogenation reactions, ${ }^{24}$ due to their high thermal stability and high efficiency. The synergistic action of two reactive sites in close proximity could be seen as a key element in the design of powerful catalysts. This prompted us to explore the catalytic activity of these dinuclear iridium complexes towards alkane dehydrogenation. The reaction of cyclooctane (COA) and $t$-butylethylene (TBE), as sacrificial olefin, to form cyclooctene (COE) and $t$-butylethane (TBA) catalyzed by the POCOP iridium pincer complex ${ }^{25}$ was employed in the benchmark reaction.

Table 3. Catalytic transfer dehydrogenation of cyclooctane in the presence of $t$-butylethylene with $\mathbf{3}_{\mathrm{H}-\mathrm{T}}, \mathbf{4}_{\mathrm{H}-\mathrm{T}}, \mathbf{5}$ and $\mathbf{7}^{a}$

\begin{tabular}{cccc} 
entry & catalyst & TON $^{b}$ & TOF $^{c} / h^{-1}$ \\
\hline 1 & $\mathbf{3}_{\mathrm{H}-\mathrm{T}}$ & 4.6 & 0.46 \\
2 & $\mathbf{4}_{\mathrm{H}-\mathrm{T}}$ & - & - \\
3 & $\mathbf{5}$ & 5.8 & 0.58 \\
4 & $\mathbf{7}$ & 62.4 & 6.24
\end{tabular}

${ }^{a}$ Reaction conditions: [Ir 2 catalyst $(0.010 \mathrm{mmol}), \mathrm{COA}(4.0 \mathrm{~mL}, 30.3 \mathrm{mmol}), \mathrm{TBE}(0.40 \mathrm{~mL}, 3.1 \mathrm{mmol}), 200{ }^{\circ} \mathrm{C}, 10 \mathrm{~h}$; ${ }^{b}$ the number of moles of COA that a mole of [Ir ${ }^{2}$ catalyst can convert in $10 \mathrm{~h} ;{ }^{c}$ turnover number per hour.

The results of preliminary experiments on the catalytic transfer dehydrogenation of COA to COE are summarized in Table 3. Using complex 7 as precursor gave better results and $2.06 \%$ of the cyclooctane was converted to cis-cyclooctene at a TOF of 6.24 $\mathrm{h}^{-1}$. This higher value compared to the other pre-catalysts is probably due to the easier de-coordination of the ethylene ligands from the iridium centres, which facilitates the metal-alkane interactions.

\section{Conclusions}

In this work, we have provided a more detailed investigation on dinuclear $\operatorname{Ir}(\mathrm{I})$ and $\mathrm{Rh}(\mathrm{I})$ complexes containing a bridging 1 arylimidazolide ligand, C2 and N3-bound to the metals. ${ }^{16 \mathrm{~b}}$ Initial deprotonation of 1-arylimidazoles (aryl = mesityl (Mes), 2,6diisopropylphenyl (Dipp)) by $n$-butyl lithium in pentane at $-30{ }^{\circ} \mathrm{C}$ was carried out to afford the corresponding derivatives (1-aryl- 
1 -imidazol-2-yl)lithium (1a,b) which were then used to prepare the doubly $\mathrm{C}, \mathrm{N}$-bridged dinuclear $\operatorname{Ir}(\mathrm{I})$ complexes $\mathbf{3}$. These $\operatorname{Ir}(\mathrm{I})$ complexes exist in two isomeric forms, $\mathbf{3}_{\mathrm{H}-\mathrm{H}}$ which is the head-to-head isomer of $C_{\mathrm{S}}$ symmetry, and $\mathbf{3}_{\mathrm{H}-\mathrm{T}}$, the head-to-tail isomer of $C_{2}$ symmetry, which is thermodynamically more stable. The $\mathrm{X}$-ray diffraction data suggest electron delocalisation within the

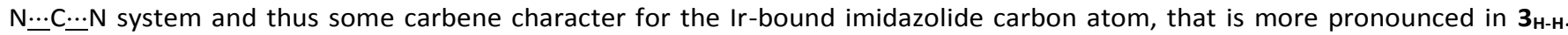
The metal-bound imidazolide may be viewed as a deprotonated pNHC system. When the tetracarbonyl derivatives $\mathbf{4}_{\mathrm{H}-\mathrm{H}}$ and $\mathbf{4}_{\mathrm{H}-\mathrm{T}}$ were reacted with $\mathrm{PMe}_{3}$, one $\mathrm{CO}$ ligand was displaced from each Ir centre and only one isomer was formed, 5, in which the imidazolide ligands are bound in a H-T manner This ligand arrangement was retained in the formally metal-metal bonded, $\mathrm{d}^{7}$ - $\mathrm{d}^{7}$ $\operatorname{Ir}(I I)-\operatorname{Ir}(\mathrm{II})$ complex, 6, resulting from oxidative-addition of Mel across 5. From the results obtained by cyclic voltammetry, exhaustive coulometry and spectroelectrochemistry, it was concluded that $\mathbf{3}_{\mathrm{H}-\mathrm{T}}$ undergoes a metal-based one electron oxidation to generate the mixed-valent $\operatorname{Ir}(\mathrm{I}) / \mathrm{Ir}(\mathrm{II})$ system, in equilibrium with $\operatorname{Ir}(\mathrm{II}) / \operatorname{Ir}(\mathrm{I})$, characterised by an IVCT band in the NIR region.

EPR studies combined with DFT calculations suggested that the $\mathrm{Ir}$ and Rh centres contribute substantially to the experimental magnetic anisotropy in the oxidized species and thus to theSOMO. These data evidenced that both $\operatorname{Ir}(\mathrm{II}) / \operatorname{Ir}(\mathrm{I})$ and $\mathrm{Rh}(\mathrm{II}) / \mathrm{Rh}(\mathrm{I})$ complexes are delocalized mixed-valent species.

The dinuclear iridium complexes were found to be only moderately active pre-catalysts in the reaction of cyclooctane and $t$ butylethylene to form cyclooctene and $t$-butylethane. Whether these results are directly linked to a difficulty to access coordinatively unsaturated and reactive species or to an inhibiting effect of the cod ligands cannot be stated at this stage. In favour of the latter hypothesis is that slightly better performances were obtained with the tetraethylene complex $\mathbf{7}$, may be due to the favourable lability of the ethylene ligands.

\section{Experimental}

\section{General Considerations}

All manipulations involving organometallics were performed under argon in a Braun glove-box or using standard Schlenk techniques. Solvents were dried using standard methods and distilled over sodium/ benzophenone under argon prior use or passed through columns of activated alumina and subsequently purged with argon. The starting materials $[\mathrm{Rh}(\operatorname{cod})(\mu-\mathrm{Cl})]_{2}{ }^{26}$ $\left[\operatorname{Ir}\left(\mathrm{C}_{2} \mathrm{H}_{4}\right)_{2}(\mu-\mathrm{Cl})\right]_{2}{ }^{12 \mathrm{~h}}$ and $\left[\mathrm{Rh}\left(\mathrm{C}_{2} \mathrm{H}_{4}\right)_{2}(\mu-\mathrm{Cl})\right]_{2}{ }^{27}$ were prepared according to the literature and $[\operatorname{Ir}(\operatorname{cod})(\mu-\mathrm{Cl})]_{2}$ is commercially available from Johnson Matthey PLC. NMR spectra of complexes were recorded on a Bruker $300 \mathrm{MHz}, 400 \mathrm{MHz}, 500 \mathrm{MHz}$ or 600 $\mathrm{MHz}$ instrument at ambient temperature and referenced using the proton $\left({ }^{1} \mathrm{H}\right)$ or carbon $\left({ }^{13} \mathrm{C}\right)$ resonance of the residual solvent, with downfield shifts reported as positive. Assignments are based on ${ }^{1} \mathrm{H},{ }^{1} \mathrm{H}-\mathrm{COSY},{ }^{1} \mathrm{H}-\mathrm{NOESY},{ }^{1} \mathrm{H} /{ }^{13} \mathrm{C}-\mathrm{HSQC}$, and ${ }^{1} \mathrm{H} /{ }^{13} \mathrm{C}-\mathrm{HMBC}$ experiments. ${ }^{31} \mathrm{P}\left\{{ }^{1} \mathrm{H}\right\}$ NMR spectra were recorded on a Bruker Avance 300 instrument at $121.49 \mathrm{MHz}$ using $\mathrm{H}_{3} \mathrm{PO}_{4}\left(85 \%\right.$ in $\left.\mathrm{D}_{2} \mathrm{O}\right)$ as external standard. IR spectra were recorded in the region $4000-100 \mathrm{~cm}^{-1}$ on a Nicolet $6700 \mathrm{FT}-\mathrm{IR}$ spectrometer (ATR mode, diamond crystal). Elemental analyses were performed by the "Service de microanalyses", Université de Strasbourg.

\section{Synthetic procedures}

(1-Mesityl-1H-imidazol-2-yl)lithium (1a). To a stirred solution of 1-mesitylimidazole (1.49 $\mathrm{g}, 8.0 \mathrm{mmol})$ in pentane (30 $\mathrm{mL})$ was added dropwise a solution of $n$-BuLi $\left(1.6 \mathrm{M}\right.$ in $n$-hexane, $5.0 \mathrm{~mL}, 8.0 \mathrm{mmol}$ ) at $-78{ }^{\circ} \mathrm{C}$ over $2 \mathrm{~min}$. The reaction mixture was stirred for $1 \mathrm{~h}$ at $-30^{\circ} \mathrm{C}$, then allowed to warm to room temperature and stirred for another $2 \mathrm{~h}$. The resulting clear orange solution was evaporated in vacuo. The residue was washed with pentane $(3 \times 5 \mathrm{~mL})$ to yield a white powder which was collected by filtration and dried in vacuo (1.08 g, 70\%). ${ }^{1} \mathrm{H}$ NMR $\left(500 \mathrm{MHz}, \mathrm{THF}_{-} \mathrm{d}_{8}\right): \delta 7.04(\mathrm{~s}, 1 \mathrm{H}, \mathrm{NCHCHN}($ mesityl) $), 6.83(\mathrm{~s}, 2 \mathrm{H}$, aryl-H), $6.70(\mathrm{~s}, 1 \mathrm{H}$, $\mathrm{NCHCHN}_{\text {(mesityl) }),} 2.25\left(\mathrm{~s}, 3 \mathrm{H}, p-\mathrm{CH}_{3 \text { (mesityl) }}\right), 1.95\left(\mathrm{~s}, 6 \mathrm{H}, o-\mathrm{CH}_{3 \text { (mesityl) }}\right) .{ }^{13} \mathrm{C}\left\{{ }^{1} \mathrm{H}\right\} \mathrm{NMR}\left(125 \mathrm{MHz}, \mathrm{THF}-\mathrm{d}_{8}\right): \delta 205.8(\mathrm{NCN}$ (mesityl) $), 142.3$ $\left(C_{(\text {mesityl) }}\right), 136.5\left(C_{(\text {mesityl) }}\right), 135.5\left(C_{(\text {mesityl) }}\right) 128.3\left(\mathrm{CH}_{(\text {mesityl) }}\right), 127.9\left(\mathrm{NCHCHN}_{(\text {mesityl) }}\right), 116.8\left(\mathrm{NCHCHN}_{(\text {mesityl) }}\right), 20.9\left(p-C \mathrm{H}_{3(\text { mesityl) }}\right), 18.2$

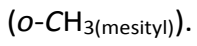

(1-(2,6-Diisopropylphenyl)-1H-imidazol-2-yl)lithium (1b). To a stirred solution of 1-(2,6-diisopropylphenyl)-imidazole (1.83 g, $8.0 \mathrm{mmol}$ ) in pentane $(30 \mathrm{~mL})$ was added dropwise a solution of $n$-BuLi $(1.6 \mathrm{M}$ in $n$-hexane, $5.0 \mathrm{~mL}, 8.0 \mathrm{mmol})$ at $-78^{\circ} \mathrm{C} \mathrm{over} 2$ $\mathrm{min}$. Then the reaction mixture was allowed to warm to room temperature and stirred for another $2 \mathrm{~h}$. The precipitate was collected by filtration, washed with pentane and dried in vacuo to obtain a white powder (1.72 g, 92\%). ${ }^{1} \mathrm{H} \mathrm{NMR} \mathrm{(500} \mathrm{MHz,} \mathrm{THF-}$ $\left.\mathrm{d}_{8}\right): \delta 7.19\left(\mathrm{t},{ }^{3} \mathrm{~J}=7.6 \mathrm{~Hz}, 1 \mathrm{H}, p\right.$-aryl-H), $7.11\left(\mathrm{~d},{ }^{3} \mathrm{~J}=7.6 \mathrm{~Hz}, 2 \mathrm{H}, m\right.$-aryl-H), $7.04\left(\mathrm{~s}, 1 \mathrm{H}, \mathrm{NCHCHN}_{(\mathrm{Dipp})}\right), 6.81(\mathrm{~s}, 1 \mathrm{H}, \mathrm{NCHCHN}(\mathrm{Dipp}))$, 2.72 (sept, $\left.{ }^{3} \mathrm{~J}=6.9 \mathrm{~Hz}, 2 \mathrm{H}, \mathrm{CH}\left(\mathrm{CH}_{3}\right)_{2}\right), 1.04\left(\mathrm{~d},{ }^{3} \mathrm{~J}=6.9 \mathrm{~Hz}, 6 \mathrm{H}, \mathrm{CH}\left(\mathrm{CH}_{3}\right)_{2}\right), 1.03\left(\mathrm{~d},{ }^{3} \mathrm{~J}=6.9 \mathrm{~Hz}, 6 \mathrm{H}, \mathrm{CH}\left(\mathrm{CH}_{3}\right)_{2}\right) .{ }^{13} \mathrm{C}\left\{{ }^{1} \mathrm{H}\right\} \mathrm{NMR}(125 \mathrm{MHz}$, THF- $\left.\mathrm{d}_{8}\right): \delta 202.3\left(\mathrm{NCN}_{(\text {Dipp })}\right), 147.4\left(C_{(\text {Dipp })}\right), 142.2\left(C_{(\text {Dipp })}\right), 127.4\left(\mathrm{NCHCHN}_{(\mathrm{Dipp})}\right), 127.1\left(\mathrm{CH}_{(\mathrm{Dipp})}\right), 123.0\left(\mathrm{CH}_{(\mathrm{Dipp})}\right), 119.0$ $\left(\mathrm{NCHCHN}(\right.$ Dipp) $), 28.3\left(\mathrm{CH}\left(\mathrm{CH}_{3}\right)_{2}\right), 25.1\left(\mathrm{CH}\left(\mathrm{CH}_{3}\right)_{2}\right), 24.3\left(\mathrm{CH}\left(\mathrm{CH}_{3}\right)_{2}\right)$.

1-Mesitylimidazolyl(cycloocta-1,5-diene)iridium(I) chloride $\quad\left[\operatorname{Ir}(\operatorname{cod}) \mathrm{Cl}_{\left.\left\{\mathrm{C}_{3} \mathrm{H}_{3} \mathbf{N}_{2}(\mathrm{Mes})-\kappa N 3\right\}\right]}\right.$ (2). A solution of 1 mesitylimidazole $(0.028 \mathrm{~g}, 0.15 \mathrm{mmol})$ in THF $(2 \mathrm{~mL})$ was added to a stirred solution of $[\operatorname{Ir}(\mathrm{cod})(\mu-\mathrm{Cl})]_{2}(0.050 \mathrm{~g}, 0.074 \mathrm{mmol})$ in THF $(2 \mathrm{~mL})$. The mixture was stirred for $1 \mathrm{~h}$ at room temperature and then the volatiles were removed in vacuo. The residue was washed with pentane $(3 \times 2 \mathrm{~mL})$ and dried under vacuum to give a yellow powder $(0.074 \mathrm{~g}, 0.14 \mathrm{mmol}, 94 \%) .{ }^{1} \mathrm{H} \mathrm{NMR}(500 \mathrm{MHz}$,

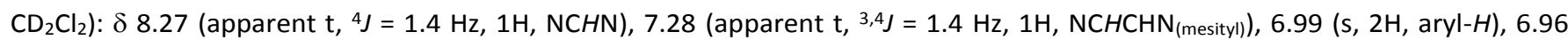

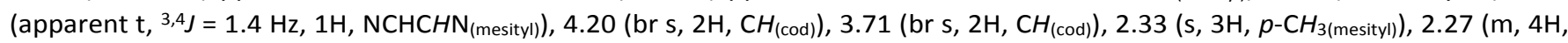


$\left.\mathrm{CH}_{2(\text { cod })}\right), 1.98\left(\mathrm{~s}, 6 \mathrm{H}, \mathrm{o}-\mathrm{CH}_{3 \text { (mesityl) }),} 1.62\left(\mathrm{~m}, 2 \mathrm{H}, \mathrm{CH}_{2 \text { (cod) })}\right), 1.51\left(\mathrm{~m}, 2 \mathrm{H}, \mathrm{CH}_{2(\text { cod })}\right) .{ }^{13} \mathrm{C}\left\{{ }^{1} \mathrm{H}\right\} \mathrm{NMR}\left(125 \mathrm{MHz}, \mathrm{CD}_{2} \mathrm{Cl}_{2}\right): \delta 140.4(\mathrm{NCHN})\right.$, $140.3\left(p-C_{(\text {mesityl) }}\right), 135.3\left(o-C_{(\text {mesityl) }}\right), 132.6$ (ipso- $\left.C_{(\text {mesityl) }}\right), 129.5\left(m-C_{(\text {mesityl) }}\right), 126.9\left(\mathrm{NCHCHN}_{(\text {mesityl) }}\right), 121.5\left(\mathrm{NCHCHN}_{(\text {mesityl) }}\right), 67.1$

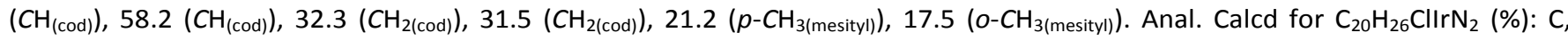
46.01; $\mathrm{H}, 5.02 ; \mathrm{N}, 5.37$. Found: $\mathrm{C}, 45.79 ; \mathrm{H}, 5.11 ; \mathrm{N}, 5.90$.

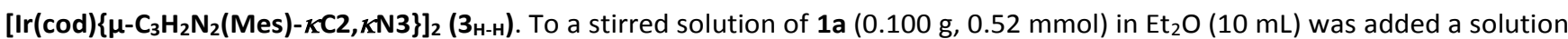
of $[\operatorname{Ir}(\operatorname{cod})(\mu-\mathrm{Cl})]_{2}(0.168 \mathrm{~g}, 0.25 \mathrm{mmol})$ in $\mathrm{Et}_{2} \mathrm{O}(5 \mathrm{~mL})$ at $-78^{\circ} \mathrm{C}$. The reaction mixture was allowed to warm to room temperature gradually and was stirred for $12 \mathrm{~h}$. After removal of the volatiles under vacuum, the residue was extracted with toluene and the solution was filtered through Celite. The filtrate was concentrated to $c a .2 \mathrm{~mL}, \mathrm{Et}_{2} \mathrm{O}(3 \mathrm{~mL})$ was added and this solution was cooled to $-30{ }^{\circ} \mathrm{C}$ to yield a dark red crystalline solid $(0.194 \mathrm{~g}, 80 \%)$ which was collected by filtration and dried in vacuo. ${ }^{1} \mathrm{H} \mathrm{NMR}$ $\left(400 \mathrm{MHz}, \mathrm{C}_{6} \mathrm{D}_{6}\right): \delta 7.20(\mathrm{~d}, 3 \mathrm{~J}=1.4 \mathrm{~Hz}, 2 \mathrm{H}, \mathrm{NCHCHN}$ (mesityl)), $6.74(\mathrm{~s}, 2 \mathrm{H}, \operatorname{aryl}-\mathrm{H}), 6.68(\mathrm{~s}, 2 \mathrm{H}, \operatorname{aryl}-\mathrm{H}), 6.42(\mathrm{~d}, 3 \mathrm{~J}=1.4 \mathrm{~Hz}, 2 \mathrm{H}$, $\left.\mathrm{NCHCHN}_{(\text {mesityl) }}\right), 4.24\left(\mathrm{~m}, 2 \mathrm{H}, \mathrm{CH}_{(\text {cod) })}\right), 3.89\left(\mathrm{~m}, 4 \mathrm{H}, \mathrm{CH}_{(\text {cod })}\right), 3.55\left(\mathrm{~m}, 2 \mathrm{H}, \mathrm{CH}_{(\text {cod })}\right), 2.65-2.31\left(\mathrm{~m}, 8 \mathrm{H}, \mathrm{CH}_{2(\mathrm{cod})}\right), 2.10(\mathrm{~s}, 12 \mathrm{H}, \mathrm{o}$ $\mathrm{CH}_{3 \text { (mesityl) }),} 1.91\left(\mathrm{~s}, 6 \mathrm{H}, p-\mathrm{CH}_{3 \text { (mesityl) }),} 1.85\left(\mathrm{~m}, 4 \mathrm{H}, \mathrm{CH}_{2(\text { cod })}\right), 1.64\left(\mathrm{~m}, 4 \mathrm{H}, \mathrm{CH}_{2(\text { cod })}\right) .{ }^{13} \mathrm{C}\left\{{ }^{1} \mathrm{H}\right\} \mathrm{NMR}\left(100 \mathrm{MHz} \mathrm{C}_{6} \mathrm{D}_{6}\right): \delta 171.3\right.$ $\left(\mathrm{NCN}_{(\text {mesityl) }}\right), 138.5\left(C_{(\text {mesityl) }}\right), 137.3\left(C_{(\text {mesityl) }}\right), 136.9\left(C_{(\text {mesityl) }}\right), 135.8\left(C_{(\text {mesityl) }}\right), 128.9\left(C_{(\text {mesityl) }}\right), 128.8\left(C \mathrm{H}_{(\text {mesityl) }}\right), 125.5$ $\left(\mathrm{NCHCHN}_{\text {(mesityl) }}\right), 122.4\left(\mathrm{NCHCHN}_{\text {(mesityl) }}\right), 69.4,69.0,65.2$ and $59.5\left(\mathrm{CH}_{\text {(cod) })}\right), 32.9,32.7,32.5$ and $32.1\left(\mathrm{CH}_{2(\text { cod })}\right), 21.0\left(p-\mathrm{CH}_{3(\text { mesityl) }}\right)$,

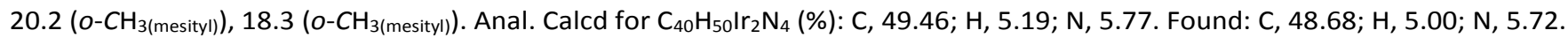

From 2: To a stirred solution of $2(0.052 \mathrm{~g}, 0.10 \mathrm{mmol})$ in THF $(5 \mathrm{~mL})$ was added a solution of KHMDS $(0.020 \mathrm{~g}, 0.10 \mathrm{mmol})$ in THF $(2 \mathrm{~mL})$ at $-78^{\circ} \mathrm{C}$. The reaction mixture was allowed to warm to room temperature gradually and was stirred for $12 \mathrm{~h}$. After removal of the volatiles under vacuum, the residue was extracted with toluene and the solution was filtered through Celite. The filtrate was evaporated to dryness under reduced pressure to yield a red solid $(0.044 \mathrm{~g}, 91 \%) .{ }^{1} \mathrm{H}$ NMR analysis of the resulting red solid revealed a ca. 40:60 mixture of $\mathbf{3}_{\mathrm{H}-\mathrm{H}}$ and $\mathbf{3}_{\mathrm{H}-\mathrm{T}}$.

[Ir(cod) $\left\{\boldsymbol{\mu}-\mathrm{C}_{3} \mathrm{H}_{2} \mathbf{N}_{\mathbf{2}}\right.$ (Mes)- $\left.\left.\boldsymbol{\kappa} \mathbf{C} 2, \boldsymbol{\kappa} \mathbf{N} 3\right\}\right]_{2}\left(\mathbf{3}_{\mathrm{H}-\mathrm{T}}\right)$. A solution of $\mathbf{3}_{\mathrm{H}-\mathrm{H}}(0.048 \mathrm{~g}, 0.050 \mathrm{mmol})$ in THF (5 mL) was refluxed for $24 \mathrm{~h}$. After removal of the solvent under vacuum, the residue was washed with pentane $(2 \times 1 \mathrm{~mL})$ to yield a purple crystalline solid $(0.046 \mathrm{~g}$, $96 \%)$ which was collected by filtration and dried in vacuo. ${ }^{1} \mathrm{H} \mathrm{NMR}\left(300 \mathrm{MHz}, \mathrm{C}_{6} \mathrm{D}_{6}\right): \delta 7.02\left(\mathrm{~d}, 3 \mathrm{~J}=1.1 \mathrm{~Hz}, 2 \mathrm{H}, \mathrm{NCHCHN}\left(\mathrm{mesity}_{1}\right)\right.$ ), $6.89(\mathrm{~s}, 2 \mathrm{H}$, aryl- $H), 6.77(\mathrm{~s}, 2 \mathrm{H}, \operatorname{aryl}-H), 6.53\left(\mathrm{~d},{ }^{3} \mathrm{~J}=1.1 \mathrm{~Hz}, 2 \mathrm{H}, \mathrm{NCHCHN}\right.$ (mesityl) $\left._{1}\right), 4.32\left(\mathrm{~m}, 2 \mathrm{H}, \mathrm{CH}_{\text {(cod) })}\right), 3.85(\mathrm{~m}, 2 \mathrm{H}, \mathrm{CH}(\mathrm{cod})), 3.66$

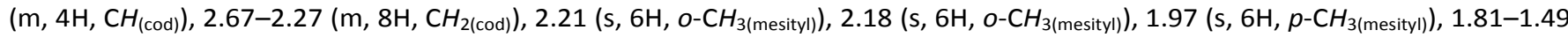
$\left.\left(\mathrm{m}, 8 \mathrm{H}, \mathrm{CH}_{2(\mathrm{cod})}\right)\right) .{ }^{13} \mathrm{C}\left\{{ }^{1} \mathrm{H}\right\} \operatorname{NMR}\left(75 \mathrm{MHz}, \mathrm{C}_{6} \mathrm{D}_{6}\right): \delta 172.0\left(\mathrm{NCN}_{(\text {mesityl) }}\right), 138.3\left(C_{(\text {mesityl) }}\right), 137.2\left(C_{(\text {mesityl) }}\right), 136.8\left(C_{(\text {mesityl) }}\right), 135.0$ $\left(C_{(\text {mesityl) })}\right), 129.3\left(\mathrm{CH}_{(\text {mesityl) }}\right), 128.1\left(\mathrm{CH}_{(\text {mesityl) }}\right), 125.4\left(\mathrm{NCHCHN}_{(\text {mesityl) }}\right), 121.3\left(\mathrm{NCHCHN}_{(\text {mesityl) }}\right), 75.7,73.8,59.8$ and $56.0\left(\mathrm{CH}_{(\text {cod })}\right)$,

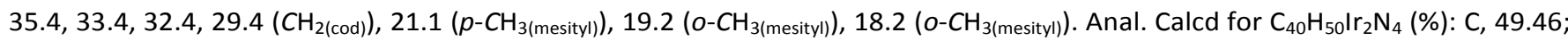
$\mathrm{H}, 5.19 ; \mathrm{N}, 5.77$. Found: $\mathrm{C}, 49.21 ; \mathrm{H}, 4.96 ; \mathrm{N}, 5.60$.

$\left[\operatorname{Ir}(\mathbf{C O})_{2}\left\{\boldsymbol{\mu}-\mathbf{C}_{3} \mathbf{H}_{2} \mathbf{N}_{\mathbf{2}} \text { (Mes)- } \boldsymbol{\kappa} \mathbf{C} 2, \boldsymbol{k} \mathbf{N} 3\right\}\right]_{2}\left(\mathbf{4}_{\mathrm{H}-\mathrm{H}}\right)$. A suspension of $\mathbf{3}_{\mathrm{H}-\mathrm{H}}(0.097 \mathrm{~g}, 0.100 \mathrm{mmol})$ in Et ${ }_{2} \mathrm{O}(5 \mathrm{~mL})$ was stirred under $\mathrm{CO}(1$ bar) at room temperature and the color turned from red to yellow immediately. The suspension was further stirred for 30 min. After removal of the volatiles under vacuum, the residue was washed with pentane $(2 \times 1 \mathrm{~mL})$ to yield a yellow crystalline solid which was collected by filtration and dried in vacuo $(0.070 \mathrm{~g}, 81 \%)$. ${ }^{1} \mathrm{H} \mathrm{NMR}\left(500 \mathrm{MHz}, \mathrm{C}_{6} \mathrm{D}_{6}\right): \delta 7.11(\mathrm{~d}, 3 \mathrm{~J}=1.5 \mathrm{~Hz}, 2 \mathrm{H}$,

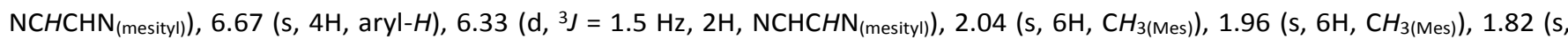
$\left.6 \mathrm{H}, \mathrm{CH}_{3(\mathrm{Mes})}\right) .{ }^{13} \mathrm{C}\left\{{ }^{1} \mathrm{H}\right\} \mathrm{NMR}\left(125 \mathrm{MHz}, \mathrm{C}_{6} \mathrm{D}_{6}\right): \delta 181.4(\mathrm{CO}), 175.5(\mathrm{CO}), 172.8\left(\mathrm{NCN}_{(\text {mesityl) }}\right), 138.7\left(C_{(\text {mesityl) }}\right), 136.8\left(C_{(\text {mesityl) }}\right), 136.4$ $\left(C_{(\text {mesityl) }}\right), 136.1\left(C_{(\text {mesityl) })}\right), 131.4\left(\mathrm{NCHCHN}_{(\text {mesityl) }}\right), 129.4\left(\mathrm{CH}_{(\text {mesityl) }}\right), 129.0\left(\mathrm{CH}_{(\text {mesityl) }}\right), 123.0\left(\left(\mathrm{NCHCHN}_{(\text {mesityl) }}\right)\right), 21.0\left(\mathrm{CH}_{3(\text { mesityl) }}\right)$,

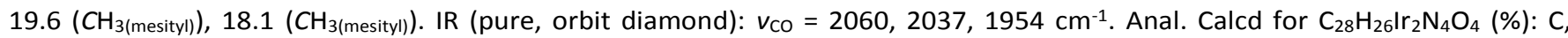
38.79; $\mathrm{H}, 3.02 ; \mathrm{N}, 6.46$. Found: $\mathrm{C}, 38.53 ; \mathrm{H}, 3.15 ; \mathrm{N}, 6.29$.

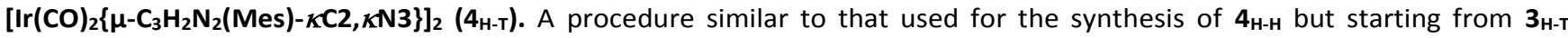
yielded a brown solid $(0.065 \mathrm{~g}, 75 \%)$. ${ }^{1} \mathrm{H}$ NMR $\left(300 \mathrm{MHz}, \mathrm{C}_{6} \mathrm{D}_{6}\right): \delta 6.95\left(\mathrm{~d},{ }^{3} \mathrm{~J}=1.6 \mathrm{~Hz}, 2 \mathrm{H}, \mathrm{NCHCHN}\left(\right.\right.$ mesityl) $\left._{1}\right), 6.79(\mathrm{~s}, 2 \mathrm{H}, \operatorname{aryl}-H), 6.77$ $\left(\mathrm{s}, 2 \mathrm{H}\right.$, aryl-H), $6.41\left(\mathrm{~d},{ }^{3} \mathrm{~J}=1.6 \mathrm{~Hz}, 2 \mathrm{H}, \mathrm{NCHCHN}(\right.$ mesityl) $), 2.09\left(\mathrm{~s}, 6 \mathrm{H}, p-\mathrm{CH}_{3(\text { mesityl) }),} 1.95\left(\mathrm{~s}, 12 \mathrm{H}, o-\mathrm{CH}_{3(\text { mesityl) }}\right) .{ }^{13} \mathrm{C}\left\{{ }^{1} \mathrm{H}\right\} \mathrm{NMR}(75 \mathrm{MHz}\right.$, $\left.\mathrm{C}_{6} \mathrm{D}_{6}\right): \delta 183.7(\mathrm{CO}), 175.7(\mathrm{CO}), 175.1\left(\mathrm{NCN}_{(\text {mesityl) }}\right), 138.7\left(C_{(\text {mesityl) }}\right), 136.5\left(C_{(\text {mesityl) }}\right), 135.6\left(C_{(\text {mesityl) }}\right), 130.5\left(\mathrm{NCHCHN}_{(\text {mesityl) }}\right), 129.4$ $\left(\mathrm{CH}_{\text {(mesityl) }}\right), 129.3\left(\mathrm{CH}_{\text {(mesityl) }),} 122.1\left(\mathrm{NCHCHN}_{\text {(mesityl) }}\right), 21.1\left(p-\mathrm{CH}_{3 \text { (mesityl) }),} 18.7\left(o-\mathrm{CH}_{3 \text { (mesityl) }}\right), 18.0\right.\right.$ (o- $\left.\mathrm{CH}_{3 \text { (mesityl) }}\right)$ IR (pure, orbit diamond): $v_{C O}=2059,2041,1968 \mathrm{~cm}^{-1}$. Anal. Calcd for $\mathrm{C}_{28} \mathrm{H}_{26} \mathrm{Ir}_{2} \mathrm{~N}_{4} \mathrm{O}_{4}(\%): \mathrm{C}, 38.79 ; \mathrm{H}, 3.02 ; \mathrm{N}, 6.46$. Found: $\mathrm{C}, 38.42 ; \mathrm{H}, 3.22 ; \mathrm{N}$, 6.63.

$\left[\operatorname{Ir}(\mathrm{CO})\left(\mathrm{PMe}_{3}\right)\left\{\mu-\mathrm{C}_{3} \mathrm{H}_{2} \mathbf{N}_{2} \text { (Mes)- } \boldsymbol{\kappa} \mathbf{C} 2, \boldsymbol{\kappa} \mathbf{N} 3\right]_{2}(\mathbf{5})\right.$. This complex can be synthesized by reaction of either $\mathbf{4}_{\mathrm{H}-\mathrm{T}}$ or $\mathbf{4}_{\mathrm{H}-\mathrm{H}}$ with 2.0 equiv. of trimethylphosphine.

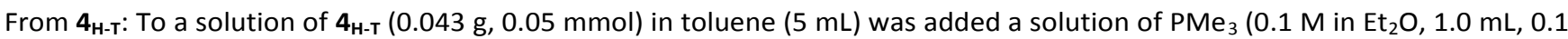
$\mathrm{mmol})$. The mixture was stirred for $4 \mathrm{~h}$ and the initially yellow solution became red. After removal of the volatiles under vacuum, the residue was washed with pentane $(2 \times 1 \mathrm{~mL})$ to yield a red crystalline solid which was collected by filtration and dried in vacuo (0.045 g, 93\%). ${ }^{1} \mathrm{H}$ NMR (500 MHz, $\left.\mathrm{C}_{6} \mathrm{D}_{6}\right): \delta 6.90\left(\mathrm{~s}, 2 \mathrm{H}\right.$, aryl- $H$ ), $6.89\left(\mathrm{~d},{ }^{3} \mathrm{~J}=1.0 \mathrm{~Hz}, 2 \mathrm{H}, \mathrm{NCHCHN}\left(\right.\right.$ mesityl) $\left._{1}\right), 6.77(\mathrm{~s}, 2 \mathrm{H}, \operatorname{aryl}-\mathrm{H})$,

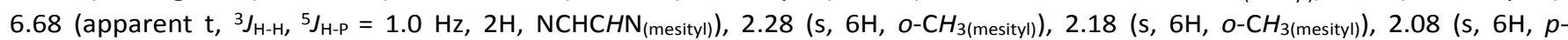

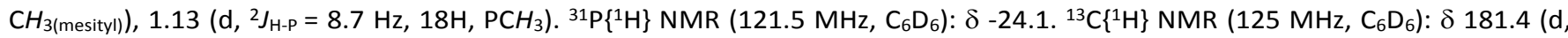
$\left.{ }^{2} J_{C-P}=10.0 \mathrm{~Hz}, C O\right), 177.1\left(\mathrm{~d},{ }^{2} J_{\mathrm{C}-\mathrm{P}}=112.0 \mathrm{~Hz}, \mathrm{NCN}(\right.$ mesityl) $), 138.3\left(C_{(\text {mesityl) }}\right), 137.5\left(C_{(\text {mesityl) }}\right), 136.7\left(C_{(\text {mesityl) }}\right), 135.5\left(C_{(\text {mesityl) }}\right), 129.4$ $\left(\mathrm{CH}_{\text {(mesityl) }}\right), 128.9\left(\mathrm{CH}_{(\text {mesityl) }}\right), 128.0\left(\mathrm{~d},{ }^{4} \mathrm{~J}_{\mathrm{C}-\mathrm{p}}=5.2 \mathrm{~Hz}, \mathrm{NCHCHN}(\right.$ mesityl) $), 120.1$ (d, $\left.{ }^{4} \mathrm{~J}_{\mathrm{C}-\mathrm{p}}=2.0 \mathrm{~Hz}, \mathrm{NCHCHN}_{(\text {mesityl) }}\right), 21.1\left(p-\mathrm{CH}_{3(\text { mesityl) }}\right)$,

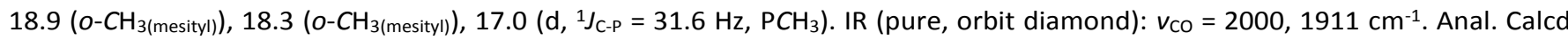
for $\mathrm{C}_{32} \mathrm{H}_{44} \mathrm{Ir}_{2} \mathrm{~N}_{4} \mathrm{O}_{2} \mathrm{P}_{2}$ (\%): C, 39.91; $\mathrm{H}, 4.60 ; \mathrm{N}, 5.82$. Found: $\mathrm{C}, 39.88 ; \mathrm{H}, 4.70 ; \mathrm{N}, 5.75$. 
From $\mathbf{4}_{\mathrm{H}-\mathrm{H}}$ : A procedure similar to that used with $\mathbf{4}_{\mathrm{H}-\mathrm{T}}$ was employed to yield the same red crystalline solid $(0.046 \mathrm{~g}, 96 \%)$.

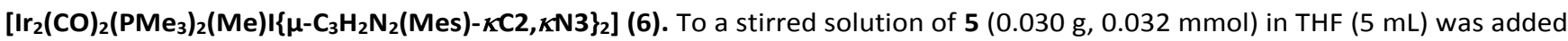
dropwise over $2 \mathrm{~min}$ a solution of $\mathrm{Mel}\left(0.1 \mathrm{M}\right.$ in Et $\left.\mathrm{E}_{2} \mathrm{O}, 0.4 \mathrm{~mL}, 0.04 \mathrm{mmol}\right)$ and the mixture was stirred for $5 \mathrm{~min}$. Concentration of the solution under vacuum to $2 \mathrm{~mL}$ followed by addition of pentane $(5 \mathrm{~mL})$ afforded the product as a yellow powder $(0.032 \mathrm{~g}$, 90\%). ${ }^{1} \mathrm{H}$ NMR $\left(500 \mathrm{MHz}, \mathrm{C}_{6} \mathrm{D}_{6}\right): \delta 7.87\left(\mathrm{~d},{ }^{3} \mathrm{~J}=1.2 \mathrm{~Hz}, 1 \mathrm{H}, \mathrm{NCHCHN}(\right.$ mesityl) $), 6.97(\mathrm{~s}, 1 \mathrm{H}$, aryl- $H), 6.89(\mathrm{~s}, 1 \mathrm{H}, \operatorname{aryl}-\mathrm{H}), 6.75(\mathrm{~s}, 2 \mathrm{H}$, $\operatorname{aryl}-H), 6.73\left(\mathrm{~d}, 3 \mathrm{~J}=1.2 \mathrm{~Hz}, 1 \mathrm{H}, \mathrm{NCHCHN}_{(\text {mesityl) }}\right), 6.19\left(\mathrm{t}, J_{\mathrm{H}-\mathrm{H}}, J_{\mathrm{H}-\mathrm{P}}=1.2 \mathrm{~Hz}, 1 \mathrm{H}, \mathrm{NCHCHN}_{(\text {mesityl) }}\right), 6.04\left(\mathrm{t}, J_{\mathrm{H}-\mathrm{H}}, J_{\mathrm{H}-\mathrm{P}}=1.2 \mathrm{~Hz}, 1 \mathrm{H}\right.$,

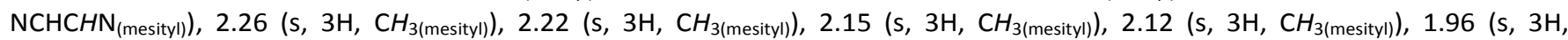

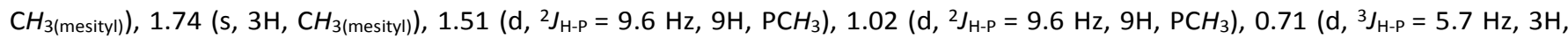
IrCH $\left.{ }_{3}\right) .{ }^{31} \mathrm{P}\left\{{ }^{1} \mathrm{H}\right\}$ NMR $\left(121.5 \mathrm{MHz}, \mathrm{C}_{6} \mathrm{D}_{6}\right): \delta-46.6,-48.9 .{ }^{13} \mathrm{C}\left\{{ }^{1} \mathrm{H}\right\} \mathrm{NMR}\left(125 \mathrm{MHz}, \mathrm{C}_{6} \mathrm{D}_{6}\right): \delta 181.5\left(\mathrm{~d},{ }^{2} J_{\mathrm{C}-\mathrm{P}}=10.5 \mathrm{~Hz}, \mathrm{CO}\right), 180.0\left(\mathrm{~d},{ }^{2} J_{\mathrm{C}-\mathrm{P}}\right.$ $=9.6 \mathrm{~Hz}, \mathrm{CO}), 142.8\left(\mathrm{~d},{ }^{2} J_{\mathrm{C}-\mathrm{p}}=136.7 \mathrm{~Hz}, \mathrm{NCN}(\right.$ mesityl)$), 140.8\left(\mathrm{~d},{ }^{2} J_{\mathrm{C}-\mathrm{p}}=141.1 \mathrm{~Hz}, \mathrm{NCN}_{(\text {mesityl) }}\right), 138.2,138.1,137.9,136.8,136.7$, $136.5,135.2$ and $135.0\left(C_{(\text {mesityl) }}\right), 131.9\left(d,{ }^{4} J_{C-P}=4.6 \mathrm{~Hz}, \mathrm{NCHCHN}\right.$ (mesityl) $\left._{1}\right), 129.8,129.1,129.0$ and $128.9\left(C_{(\text {mesityl) }}\right), 122.2\left(d,{ }^{4} J_{C-p}=\right.$ $\left.3.8 \mathrm{~Hz}, \mathrm{NCHCHN}_{(\text {mesityl) }}\right), 121.5\left(\mathrm{~d},{ }^{4} J_{\mathrm{C}-\mathrm{P}}=3.8 \mathrm{~Hz}, \mathrm{NCHCHN}_{(\text {mesityl) }}\right), 121.0\left(\mathrm{~d},{ }^{4} J_{\mathrm{C}-\mathrm{p}}=3.7 \mathrm{~Hz}, \mathrm{NCHCHN}_{(\text {mesityl) }}\right), 21.4\left(\mathrm{CH}_{3(\text { mesityl) }}\right), 21.2$

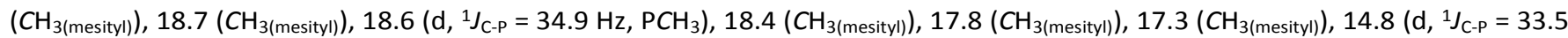
$\left.\mathrm{Hz}, \mathrm{PCH}_{3}\right),-31.8\left(\mathrm{~d},{ }^{2} \mathrm{~J}_{\mathrm{C}-\mathrm{P}}=2.3 \mathrm{~Hz}, \operatorname{IrCH} \mathrm{H}_{3}\right)$. IR (pure, orbit diamond): $v_{\mathrm{CO}}=2019,1952 \mathrm{~cm}^{-1}$. Anal. Calcd for $\mathrm{C}_{33} \mathrm{H}_{47} \mathrm{IIr}_{2} \mathrm{~N}_{4} \mathrm{O}_{2} \mathrm{P}_{2}(\%): \mathrm{C}_{\text {, }}$ 35.87; H, 4.29; N, 5.07. Found: C, 35.33; H, 4.02; N, 5.21.

$\left[\operatorname{Ir}\left(\mathrm{C}_{2} \mathrm{H}_{4}\right)_{2}\left\{\mu-\mathrm{C}_{3} \mathrm{H}_{2} \mathbf{N}_{2} \text { (Mes)- } \kappa \mathbf{C} 2, \kappa N 3\right\}\right]_{2}$ (7). To a stirred solution of $1 \mathbf{1 a}(0.100 \mathrm{~g}, 0.52 \mathrm{mmol})$ in $\mathrm{Et}_{2} \mathrm{O}(10 \mathrm{~mL})$ was added a solution of $\left[\operatorname{lr}\left(\mathrm{C}_{2} \mathrm{H}_{4}\right)_{2}(\mu-\mathrm{Cl})\right]_{2}(0.142 \mathrm{~g}, 0.25 \mathrm{mmol})$ in $\mathrm{Et}_{2} \mathrm{O}(5 \mathrm{~mL})$ at $-78^{\circ} \mathrm{C}$. The reaction mixture was allowed to warm to room temperature gradually and was further stirred for $4 \mathrm{~h}$. After removal of volatiles in vacuo, the residue was extracted with toluene and the solution was filtered through Celite. After evaporation of the toluene, the solid was washed with pentane $(2 \times 1 \mathrm{~mL})$ at $0{ }^{\circ} \mathrm{C}$ and dried in vacuo to yield a blue solid, which was stored at $-30{ }^{\circ} \mathrm{C}(0.167 \mathrm{~g}, 77 \%) .{ }^{1} \mathrm{H} \mathrm{NMR}\left(600 \mathrm{MHz}, \mathrm{C}_{6} \mathrm{D}_{6}\right): \delta 7.09(\mathrm{~d}, 3 \mathrm{~J}=1.5 \mathrm{~Hz}, 2 \mathrm{H}$,

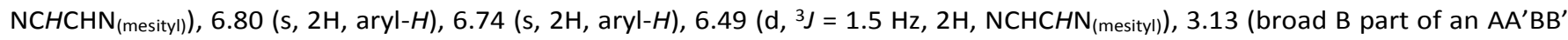

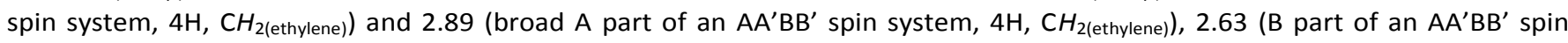

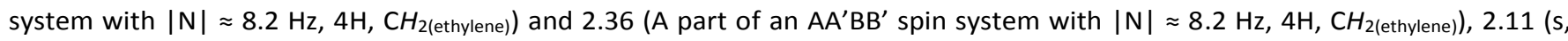

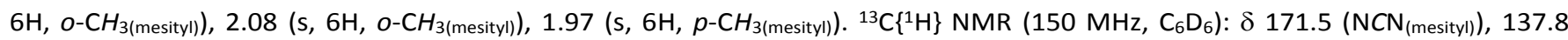

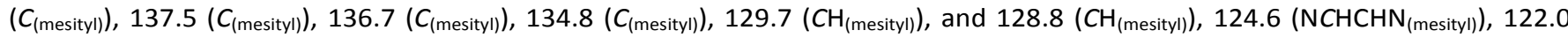
$\left(\mathrm{NCHCHN}_{(\text {mesityl) }}\right), 60.5\left(\mathrm{CH}_{2 \text { (ethylene) })}\right), 42.3\left(\mathrm{CH}_{2 \text { (ethylene) })}\right), 21.5\left(p-\mathrm{CH}_{3 \text { (mesityl) }),} 19.0\left(o-\mathrm{CH}_{3(\text { mesityl) }}\right), 18.1\right.$ (o- $\left.\mathrm{CH}_{3(\text { mesityl) }}\right)$. Calcd for $\mathrm{C}_{32} \mathrm{H}_{42} \mathrm{Ir}_{2} \mathrm{~N}_{4}(\%): \mathrm{C}, 44.32 ; \mathrm{H}, 4.88 ; \mathrm{N}, 6.46$. Found: $\mathrm{C}, 43.88 ; \mathrm{H}, 4.95 ; \mathrm{N}, 6.73$.

$\left[\mathrm{Rh}(\mathrm{cod})\left\{\boldsymbol{\mu}-\mathrm{C}_{3} \mathrm{H}_{2} \mathbf{N}_{2} \text { (Mes) }-\boldsymbol{K} \mathbf{C} 2, \boldsymbol{K} \mathbf{N} 3\right\}\right]_{2}$ (8). A procedure similar to that used for the synthesis of $\mathbf{3}_{\mathrm{H}-\mathrm{H}}$ was used but starting from $[\mathrm{Rh}(\operatorname{cod})(\mu-\mathrm{Cl})]_{2}$. Treatment of $1 \mathrm{a}(0.100 \mathrm{~g}, 0.52 \mathrm{mmol})$ with $[\mathrm{Rh}(\operatorname{cod})(\mu-\mathrm{Cl})]_{2}(0.123 \mathrm{~g}, 0.25 \mathrm{mmol})$ afforded an orange solid $(0.168$ g, 85\%). ${ }^{1} \mathrm{H}$ NMR (500 MHz, $\mathrm{C}_{6} \mathrm{D}_{6}$ ): $\delta 6.96$ (an overlap of two s, $4 \mathrm{H}, \mathrm{NCHCHN}$ (mesityl) and aryl-H), $6.77(\mathrm{~s}, 2 \mathrm{H}$, aryl- $H$ ), $6.51(\mathrm{~s}, 2 \mathrm{H}$, $\left.\mathrm{NCHCHN}_{(\text {mesityl) }}\right), 4.72\left(\mathrm{~m}, 2 \mathrm{H}, \mathrm{CH}_{(\text {(cod) })}\right), 4.48\left(\mathrm{~m}, 2 \mathrm{H}, \mathrm{CH}_{(\text {cod) })}\right), 4.09\left(\mathrm{~m}, 2 \mathrm{H}, \mathrm{CH}_{(\text {cod })}\right), 3.76\left(\mathrm{~m}, 2 \mathrm{H}, \mathrm{CH}_{\text {(cod) }}\right), 2.73-2.55\left(\mathrm{~m}, 4 \mathrm{H}, \mathrm{CH}_{2(\mathrm{cod})}\right)$,

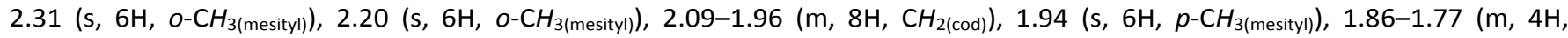
$\left.\mathrm{CH}_{2(\text { cod })}\right) .{ }^{13} \mathrm{C}\left\{{ }^{1} \mathrm{H}\right\}$ NMR $\left(125 \mathrm{MHz}, \mathrm{C}_{6} \mathrm{D}_{6}\right): \delta 176.2\left(\mathrm{~d},{ }^{1} J_{\mathrm{C}-\mathrm{Rh}}=50.4 \mathrm{~Hz}, \mathrm{NCN}(\right.$ mesityl) $), 138.8\left(C_{(\text {mesityl) }}\right), 137.2\left(C_{(\text {mesityl) }}\right), 137.0\left(C_{(\text {mesityl) }}\right)$, $135.1\left(C_{(\text {mesityl) }}\right), 129.3\left(\mathrm{CH}_{\text {(mesityl) }}\right), 128.6\left(\mathrm{CH}_{\text {(mesityl) }}\right), 126.8(\mathrm{NCHCHN}$ (mesityl) $), 120.3\left(\mathrm{NCHCHN}_{(\text {mesityl) }}\right), 90.3\left(\mathrm{~d},{ }^{1} \mathrm{~J}_{\mathrm{C}-\mathrm{Rh}}=8.4 \mathrm{~Hz}, \mathrm{CH}(\right.$ cod) $\left.)\right)$, $89.3\left(\mathrm{~d},{ }^{1} J_{\mathrm{C}-\mathrm{Rh}}=7.3 \mathrm{~Hz}, \mathrm{CH}_{(\mathrm{cod})}\right), 79.2\left(\mathrm{~d},{ }^{1} \mathrm{~J}_{\mathrm{C}-\mathrm{Rh}}=12.9 \mathrm{~Hz}, \mathrm{CH}_{(\mathrm{cod})}\right), 72.0\left(\mathrm{~d},{ }^{1} \mathrm{~J}_{\mathrm{C}-\mathrm{Rh}}=11.9 \mathrm{~Hz}, \mathrm{CH}_{(\mathrm{cod})}\right), 33.4,33.3,30.7 \mathrm{and} 29.6\left(\mathrm{CH}_{2(\mathrm{cod})}\right)$,

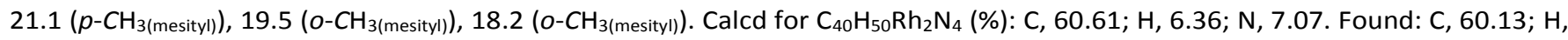
$6.48 ; \mathrm{N}, 7.32$.

$\left[R h\left(C_{2} \mathrm{H}_{4}\right)_{2}\left\{\boldsymbol{\mu}-\mathrm{C}_{3} \mathrm{H}_{2} \mathbf{N}_{2} \text { (Dipp)- } \kappa \mathbf{C} 2, \kappa \mathbf{N} 3\right\}\right]_{2}$ (9). To a stirred solution of $\mathbf{1 b}(0.120 \mathrm{~g}, 0.51 \mathrm{mmol})$ in $\mathrm{Et}_{2} \mathrm{O}$ (10 mL) was added a solution of $\left[\mathrm{Rh}\left(\mathrm{C}_{2} \mathrm{H}_{4}\right)_{2}(\mu-\mathrm{Cl})\right]_{2}(0.085 \mathrm{~g}, 0.25 \mathrm{mmol})$ in $\mathrm{Et}_{2} \mathrm{O}(5 \mathrm{~mL})$ at $-78{ }^{\circ} \mathrm{C}$. The reaction mixture was allowed to warm to room temperature gradually and was further stirred for $4 \mathrm{~h}$. After removal of the volatiles under vacuum, the residue was extracted with $n$-hexane and the solution was filtered through Celite. The filtrate was concentrated to ca. $4 \mathrm{~mL}$ under reduced presssure and then was cooled to $-30{ }^{\circ} \mathrm{C}$ in an ethylene atmosphere to obtain purple crystals, which were stored at $-30{ }^{\circ} \mathrm{C}(0.135 \mathrm{~g}, 70 \%)$. ${ }^{1} \mathrm{H}$ NMR $\left(400 \mathrm{MHz}, \mathrm{C}_{6} \mathrm{D}_{6}\right): \delta 7.28\left(\mathrm{~d},{ }^{3} \mathrm{~J}=4.4 \mathrm{~Hz}, 4 \mathrm{H}, m\right.$-aryl- $H$ ), $7.08(\mathrm{t}, 3 \mathrm{~J}=4.4 \mathrm{~Hz}, 2 \mathrm{H}, p$-aryl-H), $7.02(\mathrm{~s}, 2 \mathrm{H}, \mathrm{NCHCHN}(\mathrm{Dipp}), 6.64(\mathrm{~s}$, $2 \mathrm{H}, \mathrm{NCHCHN}_{(\mathrm{Dipp})}$ ), 3.65 (B part of a broad poorly resolved $\mathrm{AA}^{\prime} \mathrm{BB}^{\prime}$ spin system, $4 \mathrm{H}, \mathrm{CH}_{2(\text { ethylene) }}$ ) and 3.58 (A part of a broad poorly

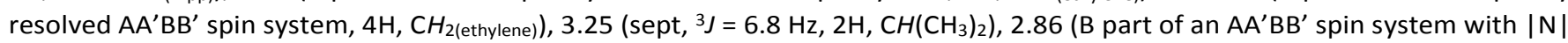

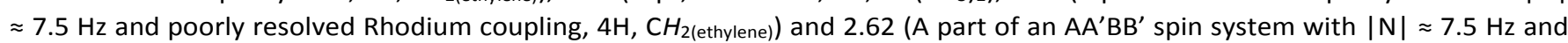
poorly resolved Rhodium coupling, $4 \mathrm{H}, \mathrm{CH}_{2}$ (ethylene)), 2.48 (sept, $\left.3 \mathrm{~J}=6.8 \mathrm{~Hz}, 2 \mathrm{H}, \mathrm{CH}\left(\mathrm{CH}_{3}\right)_{2}\right), 1.73\left(\mathrm{~d}, 3 \mathrm{~J}=6.8 \mathrm{~Hz}, 6 \mathrm{H}, \mathrm{CH}(\mathrm{CH})_{2}\right), 1.16$ $\left(\mathrm{d},{ }^{3} \mathrm{~J}=6.8 \mathrm{~Hz}, 6 \mathrm{H}, \mathrm{CH}\left(\mathrm{CH}_{3}\right)_{2}\right), 1.06\left(\mathrm{~d},{ }^{3} \mathrm{~J}=6.8 \mathrm{~Hz}, 6 \mathrm{H}, \mathrm{CH}\left(\mathrm{CH}_{3}\right)_{2}\right), 0.80\left(\mathrm{~d},{ }^{3} \mathrm{~J}=6.8 \mathrm{~Hz}, 6 \mathrm{H}, \mathrm{CH}\left(\mathrm{CH}_{3}\right)_{2}\right) .{ }^{13} \mathrm{C}\left\{{ }^{1} \mathrm{H}\right\} \mathrm{NMR}\left(100 \mathrm{MHz}, \mathrm{C}_{6} \mathrm{D}_{6}\right): \delta$ $175.1\left(\mathrm{~d},{ }^{1} J_{\mathrm{C}-\mathrm{Rh}}=49.0 \mathrm{~Hz}, \mathrm{NCN}(\mathrm{Dipp})\right), 147.1\left(C_{(\mathrm{Dipp})}\right), 146.1\left(C_{(\text {Dipp })}\right), 137.8\left(C_{(\mathrm{Dipp})}\right), 128.9\left(\mathrm{CH}_{(\mathrm{Dipp})}\right), 125.9(\mathrm{NCHCHN}(\mathrm{Dipp})), 124.1$ $\left(\mathrm{CH}_{(\text {Dipp })}\right), 123.8\left(\mathrm{CH}_{(\text {Dipp })}\right), 122.8\left(\mathrm{NCHCHN}_{(\text {Dipp })}\right), 78.7\left(\mathrm{~d},{ }^{1} \mathrm{~J}_{\mathrm{C}-\mathrm{Rh}}=6.6 \mathrm{~Hz}, \mathrm{CH}_{2 \text { (ethylene) })}\right), 58.0\left(\mathrm{~d},{ }^{1} J_{\mathrm{C}-\mathrm{Rh}}=12.1 \mathrm{~Hz}, \mathrm{CH}_{2(\text { ethylene) })}\right), 28.8$ $\left(\mathrm{CH}\left(\mathrm{CH}_{3}\right)_{2}\right), 28.3\left(\mathrm{CH}\left(\mathrm{CH}_{3}\right)_{2}\right), 26.3,24.9,24.2$ and $23.4\left(\mathrm{CH}\left(\mathrm{CH}_{3}\right)_{2}\right)$. Calcd for $\mathrm{C}_{38} \mathrm{H}_{54} \mathrm{Rh}_{2} \mathrm{~N}_{4}(\%): \mathrm{C}, 59.07 ; \mathrm{H}, 7.04 ; \mathrm{N}, 7.25$. Found: $\mathrm{C}$, $58.63 ; \mathrm{H}, 6.87 ; \mathrm{N}, 7.42$.

\section{Catalytic transfer dehydrogenation of cyclooctane.}

In a preliminary investigation, a red suspension of complex $\mathbf{3}_{\mathrm{H}-\mathrm{T}}(9.7 \mathrm{mg}, 0.010 \mathrm{mmol})$ in a mixture of COA (4.0 mL, $\left.30.3 \mathrm{mmol}\right)$ and TBE $(0.40 \mathrm{~mL}, 3.1 \mathrm{mmol})$, in a sealed tube under argon, was heated at $200{ }^{\circ} \mathrm{C}$ for $10 \mathrm{~h}$ (Table 3, entry 1). Gas chromatographic (GC) analysis of the products indicated $0.15 \%$ of the cyclooctane was converted to cis-cyclooctene at a turnover 
frequency (TOF) $0.46 \mathrm{~h}^{-1}$. The formation of TBA, confirmed by GC and ${ }^{1} \mathrm{H}$ NMR analysis, also indicated that the transfer dehydrogenation reaction did occur. When complex $\mathbf{4}_{\mathrm{H}-\mathrm{T}}$ was used as the precatalyst under the same reaction conditions (Table 3 , entry 2), no catalytic activity was observed. In the catalytic reaction using complex 5 (Table 3, entry 3 ), in which two CO ligands of complex 4 are replaced by two molecules of $\mathrm{PMe}_{3}, \mathrm{GC}$ analysis of the products indicated that $0.19 \%$ of the cyclooctane was converted to cis-cyclooctene at a TOF of $0.58 \mathrm{~h}^{-1}$. Better results were obtained with complex 7 where $2.06 \%$ of the cyclooctane was converted to cis-cyclooctene at a TOF of $6.24 \mathrm{~h}^{-1}$.

\section{X-ray Data Collection, Structure Solution, and Refinement for All Compounds.}

Suitable crystals for the X-ray analysis of all compounds were obtained as described above. Data for $\mathbf{3}_{\mathrm{H}-\mathrm{H}}, \mathbf{3}_{\mathrm{H}-\mathrm{T}}$ and $\mathbf{8}$ were collected on an APEX-II CCD (graphite-monochromated Mo-K $\alpha$ radiation, $\lambda=0.71073 \AA$ ) at $173(2) \mathrm{K}$ and data for 9 were collected on a Kappa CCD diffractometer (graphite-monochromated Mo-K $\alpha$ radiation, $\lambda=0.71073 \AA$ ) at $173(2) \mathrm{K}$. Crystallographic and experimental details for these structures are summarized in Table S1. The structures were solved by direct methods (SHELXS$97^{28}$ ) and refined by full-matrix least-squares procedures (based on $F^{2}$, SHELXL-97) with anisotropic thermal parameters for all the non-hydrogen atoms. The hydrogen atoms were introduced into the geometrically calculated positions (SHELXS-97 procedures). The SQUEEZE instruction in PLATON was applied for $\mathbf{9}$ and the residual electron density was assigned to half a molecule of disordered $n$-hexane. In 9, one methyl group (C11) was found disordered over two positions.

\section{Electrochemistry}

All compounds were studied in $\mathrm{CH}_{2} \mathrm{Cl}_{2}+0.1 \mathrm{mM}\left[n-\mathrm{Bu}_{4} \mathrm{~N}\right] \mathrm{PF}_{6}$. [n- $\left.\mathrm{Bu}_{4} \mathrm{~N}\right] \mathrm{PF}_{6}$ (Fluka, electrochemical grade) and $\mathrm{CH}_{2} \mathrm{Cl}_{2}(\mathrm{Merck}$ $\mathrm{UVasol}^{\circ}$ ) were used as received. The electrochemical measurements were carried out at room temperature $\left(20{ }^{\circ} \mathrm{C}\right)$ in $\mathrm{CH}_{2} \mathrm{Cl}_{2}$ containing $0.1 \mathrm{M}\left[n-\mathrm{Bu}_{4} \mathrm{~N}\right] \mathrm{PF}_{6}$ in a classical three-electrode cell. The electrolyte was degassed by bubbling argon through the solution for at least $5 \mathrm{~min}$, and an argon flow was kept over the solution during measurements. The electrochemical cell was connected to a computerized multipurpose electrochemical device (Autolab, Eco Chemie BV, The Netherlands) controlled by a GPES software (v. 4.7) running on a PC computer. The working electrode was a glassy carbon (GC) disk electrode (diameter: 3 $\mathrm{mm})$, used either motionless for cyclic voltammetry $\left(100 \mathrm{mV} \mathrm{s}^{-1}\right.$ to $\left.10 \mathrm{~V} \mathrm{~s}^{-1}\right)$ or as a rotating disk electrode. The auxiliary electrode was a Pt wire, and the pseudo reference electrode a Pt wire. All potentials are given vs. $\mathrm{Fc}^{+} / \mathrm{Fc}_{\mathrm{c}}$ used as internal reference in agreement with the IUPAC recommendation ${ }^{29}$ and are uncorrected from ohmic drop.

The number of exchanged electrons for the first oxidation step was determined by exhaustive electrolysis. Prior to electrolysis, the corresponding mixtures were stirred and degassed by bubbling argon through the solution for $10 \mathrm{~min}$. Then, the desired working potential was applied. During anodic oxidation, the electrolyzed solution was continuously stirred and maintained under argon. Coulometric measurements were performed in a standard $40 \mathrm{~mL}$ cell. The working and the auxiliary electrodes were a platinum wire (o.d. $0.8 \mathrm{~mm}$ ) of $15 \mathrm{~cm}$ length. For the controlled-potential electrolysis, the anodic and cathodic compartments were separated by a fritted glass disk to prevent diffusion of the electrogenerated species.

The reference electrode was a saturated calomel electrode (SCE) that was electrically connected to the studied solution by a junction bridge filled with the corresponding solvent-supporting electrolyte solution.

Spectroelectrochemical experiments were carried out as described elsewhere, ${ }^{30}$ using a Zeiss MCS 601 UV-vis-NIR diode array spectrometer.

\section{UV-visible-NIR spectroscopy}

UV-Vis absorption spectra have been recorded for $4.4110^{-5} \mathrm{~mol} \mathrm{~L}^{-1}\left(\mathbf{3}_{\mathrm{H}-\mathrm{T}}\right)$ and $8.0710^{-5} \mathrm{~mol} \mathrm{~L}^{-1}(\mathbf{8})$ solutions in $\mathrm{CH}_{2} \mathrm{Cl}_{2}$ on a PerkinElmer Lambda 35 spectrophotometer in quartz cells $(1 \mathrm{~cm})$. The UV-visible-NIR absorption spectroscopic measurements were performed in $\mathrm{CH}_{2} \mathrm{Cl}_{2}$. The optical absorption spectrum of $\mathbf{3}_{\mathrm{H}-\mathrm{T}}$ (Figure S3) was characterised by a band in the visible domain around $525 \mathrm{~nm}\left(\varepsilon_{525 \mathrm{~nm}}=3648 \mathrm{dm}^{3} \mathrm{~mol}^{-1} \mathrm{~cm}^{-1}\right)$. In the case of the 8 (Figure S4), the band was observed at $476 \mathrm{~nm}\left(\varepsilon_{476 \mathrm{~nm}}=4585\right.$ $\left.\mathrm{dm}^{3} \mathrm{~mol}^{-1} \mathrm{~cm}^{-1}\right)$.

\section{EPR experiments}

EPR spectra were recorded with an EMX spectrometer (Bruker) operating at X-band and equipped with a standard HSN cavity and a variable temperature attachment. Computer simulations of the EPR spectra were performed with the help of Easy Spin software. ${ }^{31}$

\section{DFT calculations}

All theoretical calculations were performed with the ORCA program package. ${ }^{32}$ Geometry optimization was carried out using the GGA functional $\mathrm{BP} 86^{33}$ and by taking advantage of the resolution of the identity (RI) approximation in the Split-RI-J34 variant with the appropriate Coulomb fitting sets. ${ }^{35}$ Increased integration grids (Grid4 and GridX4 in ORCA convention) and tight SCF convergence criteria were used. Solvent effects were accounted for according to the experimental conditions. For that purpose, we used the $\mathrm{CH}_{2} \mathrm{Cl}_{2}(\square \square=9.08$ ) solvent within the framework of the conductor like screening (COSMO) dielectric continuum approach. ${ }^{36}$ Electronic structures were 
obtained from single-point calculations using the B3LYP ${ }^{37}$ functional. Scalar relativistic effects were included using the scalar relativisitc zero-order regular approximation (ZORA) ${ }^{38}$ and the scalar relativistically recontracted (SARC) ${ }^{39}$ version of the def2-TZVP(-f) basis set together with the decontracted def2-TZVP/J Coulomb fitting basis sets for all atoms. Spin density and molecular orbitals were plotted using the orca_plot utility program and visualized with Chemcraft ${ }^{40}$ software.

\section{Acknowledgements}

The USIAS, CNRS, UdS, Région Alsace and Communauté Urbaine de Strasbourg are gratefully acknowledged for the award of fellowships and a Gutenberg Excellence Chair (2010-11) to AAD and support. We also thank the ucFRC (www.icfrc.fr) for support and the China Scholarship Council for a PhD grant to F. H., and the Service de Radiocristallographie (Institut de Chimie, Strasbourg) for the determination of the crystal structures.

\section{Notes and references}

